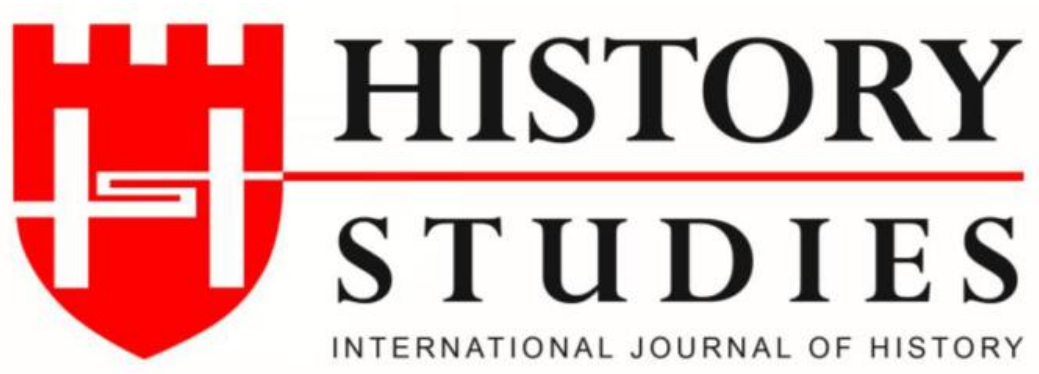

ISSN: 13094173 (Online) 1309 - 4688 (Print)

Volume 12 Issue 3, June 2020

DOI Number: 10.9737/hist.2020.867

Araştırma Makalesi

Makalenin Geliş Tarihi: 20.05.2020 Kabul Tarihi: 31.05.2020

Atıf Künyesi: Hakan Tan, “Osmanlı Devleti'nde Hapishanelerin Islah Çalışmalarına Dair Bir

İnceleme: Çarşamba Hapishanesi", History Studies, 12/3, Haziran 2020, s. 1057-1084.

\title{
Osmanlı Devleti’nde Hapishanelerin Islah Çalışmalarına Dair Bir İnceleme: Çarşamba Hapishanesi
}

\section{A Study On The Reform of Prisons In The Ottoman Empire: The Prison of Çarşamba}

\author{
Dr. Hakan Tan \\ ORCID No: 0000-0003-3420-176X \\ Ondokuz Mayıs Üniversitesi
}

Öz: XIX. asır genel itibariyle değerlendirildiğinde Osmanlı Devleti açısından pek çok alanda yenileşme hareketlerinin görüldüğü yüzyıl olmuştur. Hapishaneler konusu ise modernleşme ve ıslah çalı̧̧malarının yürütüldüğü alanlardan sadece biridir. Suç ve suçluların daha sistematik bir biçimde ele alınmasına ve diğer birtakım standartlara duyulan gereksinim suçluların tutuldukları alanların ve mevcut koşulların ıslah edilmesini kaçınılmaz kılmıştır. Bu kapsamda Osmanlı Devleti'nin de yeni hapishaneler oluşturmaya ve mevcut yapılar özelinde iyileştirme hareketine giriştiği anlaşılmaktadır. Özellikle Islahat Fermanı'ndan sonra yaygınlaşmaya başlayan hapishaneler ülke topraklarının her köşesinde görülmeye başlanmış ve bu hususta yapıların tamirinden, mahkûmların yaşam koşullarına hatta hapishanelerde görev yapan personellerin seçilmesine kadar pek çok alanda çalışmalar gerçekleştirilmiştir. Bu çalışmada ise Trabzon Vilayeti'nin Canik Sancağı'na bağlı Çarşamba kazasında bulunan hapishane ele alınmaktadır.

Anahtar Kelimeler: Çarşamba, Hapishane, Islah, Modernleşme.

Abstract: Considering the 19th century in general, it was the century in which modernization movements were seen in many areas for the Ottoman Empire. The prison subject is just one of the areas which modernization and reformation works are carried out. The need for dealing the crime and criminals more systematically and some other standards made the improvement in the areas where criminal were kept and current conditions inevitable. In this context, it is understood that the Ottoman Empire started to create new prisons and to improve existing ones. The prison, becoming common especially after the Reform Edict of 1856, started to be seen in the every corner of the country and in this respect, some works were carried out in many areas from the repair of the buildings to the living conditions of prisoners and even the selection of the personnel working in the prisons. In this study, the prison in Çarşamba which was district of Canik in the province of Trabzon is discussed.

Keywords: Çarşamba, Prison, Reform, Modernization. 
Giriş

Osmanlı Devleti XIX. yüzyılın ikinci çeyreğinden itibaren Gülhane Hatt-1 Hümayunu (1839) ve Islahat Fermanı (1856) ile birlikte birçok alanda yenileşme ve sslah çalışmaları gerçekleştirmeye başlamıştır. Mevcut pek çok kurumda sslah çalışmaları yürütüldüğü gibi çağın gereklerine uygun yeni kurumlar da ihdas edilmiştir. Yine bu dönemde Avrupa'daki gelişmeler yakından takip edilmiş ve oradaki örneklerden faydalanılma yoluna gidilmiştir.

Hapishaneler konusu da modernleşme ve ıslah çalışmalarının yürütüldüğü alanlardan birisi olarak karşımıza çıkmaktadır. Sözlükte, suçlananların haps ve tevkifine mahsus, mahfuz mahal olarak tanımlanan hapishane; davası görülünceye kadar kaçmamak için bir yere kapama anlamındaki Arapça haps kelimesinden türemiştir. ${ }^{1}$ Bir diğer deyişle, hürriyeti bağlayıcı cezaların infaz mahallidir. ${ }^{2}$

Osmanlı hukuku açısından hapishane mevzuuna bakıldığında hapis kavramının XIX. yüzyıl öncesinde tutuklama ile özdeş olduğu ifade edilebilir. Bu nedenle de suçlulara mahsus özel hapishaneler inşa edilmemiştir. Suçlular daha çok kalelerdeki zindanlara konulmuştur. II. Mahmud döneminde ise birçok alanda olduğu gibi hukuk alanında da önemli değişimler gerçekleşmiş ve 1831 yılında İstanbul'da ilk defa genel bir hapishane kurulmuştur. Tanzimat Fermanı'nın ilanından sonra da 1840, 1851 ve 1858 yıllarında gerçekleştirilen düzenlemelerle beraber Osmanlı Devleti modern anlamda ilk hapishaneler ile tanışmaya başlamıştır. ${ }^{3}$

$\mathrm{Bu}$ süreçte Osmanlı hapishaneleri ile ilgili en önemli gelişmelerden birisi de Islahat Fermanı'nda da konuya değinilmiş olmasıdır. Fermanda " 'mazanne-i sûi olanların ve yâhûd te'dîbât-ı cezâ'iyyeye müstehak bulunanların habs ve tevkiflerine mahsus olan kâffe-i mahbes ve mahall-i sâ'irede usûl-i habsiyyenin mümkün mertebe müddet-i kalîle zarfinda ıslahına mübâşeret olunması" ifadesiyle hapishane konusu ele alınmış ve hapis sürelerinin de kısa tutulması üzerinde durulmuştur. Bu gelişmeler üzerine Osmanlı bürokratları fermanın ilanından bir ay kadar sonra 1856 yılı Maliye Hazinesi bütçesi masraf kalemine "hapishaneler için tertib olunan" başlığı altında 2,500,000 kuruş ödenek koymuşlardır. ${ }^{4}$

Osmanlı'daki hapishaneler konusu ile yabancı devletler de yakından ilgilenmişler hatta Osmanlı'yı bu hususta harekete geçirmek için büyük çaba sarf etmişlerdir. Bu devletlerin başında ise şüphesiz İngiltere gelmekteydi. Konu hakkında İngiltere elçisi Canning'in Osmanlı ceza sistemi ve hapishaneler üzerindeki çalışmaları oldukça dikkat çekicidir. Osmanlı mahbeslerinin Avrupa'daki benzerleri doğrultusunda 1slah edilmesi gerektiğini gündeme getiren ve savunan elçi, Osmanlı'daki durum hakkında payitahttaki mahbeslerin kendi ülkesindekilerin iki ya da üç asır önceki halini andırdıklarını ifade etmekte ve mevcut durumu ortaya koymaktadır. ${ }^{5}$ Hapishaneler konusunu iyiden iyiye gündemine alan Canning, 1850

\footnotetext{
${ }^{1}$ Şemsettin Sami, Kâmus-ı Türkî, Yeditepe Yayınları, İstanbul, 2015, s.539, 540.

${ }^{2}$ Türk Hukuk Lügatı, 3. Baskı, Başbakanlık Basımevi, Ankara 1991, s.116.

${ }^{3}$ Eyyup Şimşek, "XX. Yüzyı1 Başlarında Trabzon Hapishanesi (1900-1914)", Karadeniz İncelemeleri Dergisi, 2017; 23, s.144.; Osmanlı Devleti'nde hapishaneler öncesinde teşhir, para cezası, küreğe koyma, sürgün gibi cezalar uygulanmaktaydı. En sık uygulanan cezalardan birisi de kalebend cezası idi. Kalebend cezası XVII. yüzyılın ilk yarısından itibaren belirgin bir şekilde uygulamaya başlanmış ve XVIII. yüzyılda yaygınlaşmıştır. Kalebend cezasına konu olan; katil, yaralama, gasp, darp, adam kaçırma, zorbalık, zulüm, hırsızlık, yol kesicilik, eşkıyalık, iftira, yalancı şahitlik, müneccimlik, ayyaşlık, yasaklanmış erzak satma, evinde suçlu saklama gibi birçok suç türü bulunmaktadır. Bkn: Ömer İşbilir, "Kalebend", Türkiye Diyanet Vakfi İslam Ansiklopedisi, C. Ek-2, İstanbul 2016, s.5.; Ayrıca Kalebend Defterlerinde geçen suç ve ceza türleri hakkında detaylı bilgi için bkn: Volkan Çeribaş, “Kalebend Defterlerinde Geçen Suç ve Ceza Türleri: 33 Numaralı Kalebend Defteri Örneği”, History Studies, 10/9, Aralık 2018, ss. 85-102.

${ }^{4}$ Gültekin Yıldız, Mapusâne Osmanlı Hapishanelerinin Kuruluş Serüveni (1839-1908), Kitabevi Yayınları, İstanbul 2010, s.165, 172.

${ }^{5}$ Canning'in bu çabasının altında yatan sebep çoğu Maltalı ve Oniki Ada kökenli Rumlar'dan oluşan ve her geçen gün sayıları artan kişilerin "himaye" için sefire sığınmalarıydı. İngiliz tüccarlarının bu bölgelerdeki faaliyetlerinde
} 
yılında Osmanlı'daki konsoloslarına 30 soruluk bir anket göndermiştir. Osmanlı mahbeslerinin durumlarına dair tespitlerin anket sorularına uygun bir şekilde cevaplanmasını ve Büyükelçiliğe iletmeleri talimatını vermişti. Konsoloslar tarafindan hazırlanan bu anketler neticesinde Canning, Haziran 1851 yılında detaylı bir raporla hapishanelerin 1slahı konusunu bir kez daha Osmanlı yetkililerinin gündemine taşımak ve onları harekete geçirmek istemiştir. ${ }^{6}$

Yaşanan bu gelişmelerle birlikte Hapishaneler Reformu yürürlüğe girmiş ve çalışmalar hız kazanmıştır. Bu kapsamda Sultanahmet Meydanı'nda 1871 senesinin ocak ayında Hapishâne-i Umûmi adıyla bir hapishane ihdas edilmiştir. Eskiden Mehterhane olarak kullanılan yapı boşaltılarak biri mûcrimîne diğeri de mahpuslara mahsus koğuşlar oluşturulmuş, hastaneler ve sanat ehli olan kimseler için uygun alanlar ile hamam, cami ve kilise gibi yapıları kapsayan bir alan oluşturulmuştur. Hatta sadrazam ve bir grup vükela tarafindan da incelemelerde bulunularak beğenilmiş, ziyaret etmek isteyenler için ise birkaç gün açık bulundurulacağı ilan edilmiştir. $^{7}$

1880 yllında ise Hapishane Reformu kapsamında önemli bir gelişme daha yaşanarak "Memâlik-i Mahrûsa-yı Şâhâne'de Bulunan Tevkifhane ve Hapishanelerin İdare-i Dahiliyelerine Dair Nizamname" adıyla altı fasıldan oluşan hapishanelere dair kapsamlı bir düzenleme yapılmıştır. $\mathrm{Bu}$ nizamnameye göre her kaza, liva ve vilayet dahilinde birer tevkifhane ve hapishane bulundurulması kararlaştırılmıştır. Tevkifhaneler sanıklara, hapishaneler ise mahkûmlara ait olup, kabahat ve cünha suçuyla üç aya kadar mahkûm olanlar kaza hapishanelerinde, üç yıla kadar hapis cezaları sancak ve üç yıldan daha fazla hapis cezaları ise vilayet hapishanelerinde çekilecektir. Ayrıca hapishanelerde kadınlara ait daire de bulunacaktır. ${ }^{8} \mathrm{Bu}$ kapsamda nizamnamenin yayınlanmasının ardından ülkenin pek çok yerinde hapishaneler açılmıştır. Bunlardan birisi de Çarşamba hapishanesidir. Bu çalışmada Osmanlı Devleti'nin son dönemlerinde hapishaneler alanında gerçekleştirmeye çalıştı̆̆ 1slah çalışmaları Çarşamba Hapishanesi özelinde incelenmeye çalışılacaktır.

Volume 12

\section{1- Hapishanenin Mevcut Durumu ve Islah Çalışmaları}

Osmanlı Devleti'nde neredeyse XIX. yüzyılın son çeyreğine kadar hapishane olarak inşa edilmiş özel yapılara rastlanılmamaktaydı. Taşrada tutuklular ve mahpuslar için hapis olarak kullanılan mekanlar daha çok şehrin en üst idari amirinin ikamet ettiği konağın tomruk dairesi veyahut mahzeniydi. ${ }^{9}$ Bazı durumlarda ise herhangi bir konağın kiralanması yoluyla hapishane olarak kullanıldığ bilinmektedir. Çarşamba hapishanesi için de kaza dahilinde hapishane şartlarına uygun ve bunun için inşa edilmiş özel bir mekân mevcut değildi. Hapishane ve

oynadıkları rol nedeniyle Safaret tarafından bu kişiler geri çevrilememekteydi. Canning'in ifadesiyle "en göze batan suçlu sınıfını oluşturan bu kişiler" haricinde İstanbul'da sokaklarda çatışıp birbirlerini bıçaklayan suçlular da Osmanlı güçlerinden kaçarak Sefaret'e sığınmaktaydılar. Bu suçluları cezalandırmak için elinde herhangi bir güç bulunmayan elçi ise Osmanlı adli sisteminin bu kişileri Tersane Zindanı'na attığını veyahut şüpheli kefaletlerle serbest bıraktığını iddia etmektedir. Yıldız, a.g.e., s. 74-77.

${ }^{6}$ İbrahim Serbestoğlu, Tanzimat, Teftiş ve Canik Sancağı'nda Modernleşme, Gece Akademi Yayınları, Ankara 2019, s.139.; Bu hususta çalışmalar yürüten ilk Avrupalı kişi Canning değildir. 1847-48 yılları arasında Osmanlı topraklarını ziyaret eden İngiliz subay Charles MacFarlane kaleme aldığı seyahatnamesinde Fransız İçişleri Bakanının dönemin Başbakanı M. Guizot tarafından Balkanlara gönderilen ekonomi profesörü M. Blanqui'den Türk mahbesleri üzerine incelemelerde bulunmasını talep ettiğinden bahsetmektedir. Yıldız, a.g.e., s.110-112.

${ }^{7}$ Ahmed Lûtfî (Efendi), Vak'a-Nüvis Ahmed Lütfí Efendi Tarihi, C.XII, Yay. M. Münir Aktepe, Türk Tarih Kurumu Yayınları, Ankara 1989, s.100.; Ömer Şen, Osmanlı'da Mahkûm Olmak, Avrupalılaşma Sürecinde Hapishaneler, Kap1 Yayınları, İstanbul 2007, s.16; Kent F. Schull, Prisons In The Late Ottoman Empire, Microcosms Of Modernity, Edinburgh University Press, Edinburgh 2014, s.45.; Hapishâne-i Umûmi hakkında daha detaylı bilgi için bkn: Yıldız, a.g.e., s.267-328.

${ }^{8}$ Mucize Ünlü, "Hapishane Reformu Sürecinde Canik Hapishanesini Islah Çalıșmaları (1876-1918)," Samsun Araştırmaları, Ed. Cevdet Yılmaz, Samsun Büyükşehir Belediyesi Kültür Yayınları, Samsun 2013, s. 247, 248.

${ }^{9}$ Yildiz, a.g.e., s. 112 
tevkifhane hükümet konağının yanındaki beș odalı bir binada aynı yerde yer almaktaydı. ${ }^{10}$ Erkek mahkûmlar için bir ve kadın mahkûmlar için de bir oda tahsis edilmiştir. Kadınlar bir dönem jandarma dairesinin alt katında bulunan eşya mahzeninde tutulmaktaydı. Hapishane hakkındaki izahat varakalarından edinilen bilgilere göre ise müdür kadrosu uzun yıllar boyunca boş kalmış, idari işler genel itibariyle bir baş gardiyan ve iki tane de gardiyan tarafından yürütülmüştür. ${ }^{11}$

Hapishane Reformu sürecinde en çok karşılaşılan ve üzerinde ehemmiyetle durulan konulardan birisi hapishane olarak kullanılan binaların fiziki yetersizlikleri ve mahkûmlar için elverişli bir ortam sunamamalarıydı. Mevcut binaların veyahut odaların özellikle temel sıhhî koşullardan uzak olduğu yerli ve yabancı uzmanların yanı sıra yerel yöneticiler tarafından da her firsatta dile getirilmiştir. Çarşamba kazası özelinde de durum pek farklı değildir. Henüz 1900'lü yılların hemen başlarında Anadolu Müfettiş-i Umumisi Şakir Paşa görevi nedeniyle bulunduğu Çarşamba'da incelemeler yapma fırsatı yakalamış ve kaza hapishanesi hakkında önemli tespitlerde bulunmuştur. Şakir Paşa, Çarşamba hapishanesinin genel sağlik kurallarından oldukça uzak olduğunu dile getirmiş ve hatta durumun ehemmiyetini daha iyi aktarabilmek için hapishaneyi adeta bir cinayet mahalline benzetmiştir. ${ }^{12}$ Paşa kazadaki hükümet konağının da pek iyi bir durumda olmadığını bu nedenle kazaya bir hükümet konağ1 ve ona ilave olarak bir de hapishane yapılmasının gerekliliğini vurgulamıştır. Bu binaların inşası için kaza halkıyla da görüşerek emek ve para yardımı yapmaları hususunda söz almış, keşif yapılması, gerekli olan meblağın belirlenmesi ve kimlerden ne kadar yardım alınacağ1 gibi hususlarda çalışmalar yaptırmıştır. İnşaat için gereken iznin ise Trabzon Valisi'ne verilmesi için Babıali ve Dahiliye Nezareti’nden talepte bulunmuş, Canik Mutasarrıflığına da çalışmaların başlatılması için emir vermiştir. ${ }^{13}$

Aradan birkaç yıl geçmiş olmasına rağmen hapishane inşaatına başlanılmadığı anlaşılmaktadır. Kazada yeni bir hapishaneye duyulan gereksinim ile ilgili birçok yazışma yapılmış ve bu amaçla kullanılan binanın nemli, aynı zamanda sağlık açısından uygun olmadığı da hemen hemen her defasında belirtilmiştir. ${ }^{14}$ Ancak bu süreç ülkedeki pek çok hapishane binası için benzer bir şekilde devam etmektedir. Çarşamba'da müstakil bir hapishane binasının yapılması konusu da yine bu süreçte yapılan yazışmalarla her defasında gündeme taşınmıştır. ${ }^{15}$ Mevcut binanın mahkûmlar için yeterli sağlık koşullarını sağlayamamasının yanında mahkûmların firar teşebbüsleri gibi öngörülemeyen bazı sorunların ortaya çıkması ve firar

\footnotetext{
${ }^{10}$ Anadolu'da Tanin yazıları ile tanınan Tanin gazetesi muhabiri Ahmet Şerif Bey, Çarşamba hapishanesinin hükümet konağının yanındaki bir binada olduğunu belirtmektedir. Ahmet Ali Gazel, "Tanin Muhabiri Ahmet Şerif Beyin Notlarında Osmanlı Hapishaneleri”, Hapishane Kitabl, Ed. Emine Gürsoy Naskali, Hilal Oytun Altun, Kitabevi Yayınları, İstanbul 2018, s.150; Osmanlı Devleti'nde hapishaneler ve tevkifhaneler genellikle aynı yerde yer almaktaydı. Tevkifhaneler, sorgulanmakta ve yargılanmakta olan sanıklara, hapishaneler ise mahkûm olanlara mahsustu. Bu durum 1880 tarihli nizamnamenin ikinci ve üçüncü maddelerinde de belirtilmektedir. Yasemin Saner Gönen, "Osmanlı İmparatorluğunda Hapishaneleri İyileştirme Girişimi, 1917 Yılı”, Hapishane Kitabl, Ed. Emine Gürsoy Naskali, Hilal Oytun Altun, Kitabevi Yayınları, İstanbul 2018, s.174.; Y1ldız, a.g.e., s.475.

${ }^{11}$ BOA (Devlet Arşivleri Başkanlığı Osmanlı Arşivi) Dahiliye Nezareti Mebani-i Emiriye-Hapishaneler Müdüriyeti Evrakı (DH. MB. HPS), 27/17, 24 Ocak 1917 (11.Kanun-1 Sani 1332).; BOA (Devlet Arşivleri Başkanlığı Osmanlı Arşivi) Dahiliye Nezareti Mebani-i Emiriye-Hapishaneler Müdüriyeti Evrakı (DH. MB. HPS), 2/7, 25 Aralık 1911 (4 Muharrem 1330).

${ }^{12}$ BOA (Devlet Arşivleri Başkanlığı Osmanlı Arşivi) Yıldız Esas Evrakı (Y. EE), 134/53, 23 Nisan 1898 (11 Mayıs 1314).

${ }^{13}$ BOA (Devlet Arşivleri Başkanlığı Osmanlı Arşivi) Dahiliye Nezareti Mektubi Kalemi (DH. MKT), 2158/59, 29 Aralık 1900 (7 Ramazan 1318).; Ali Karaca, Anadolu Islahâtı ve Ahmet Şâkir Paşa (1838-1899), Eren Yayınları, İstanbul 1993, s.125.

${ }^{14}$ BOA (Devlet Arşivleri Başkanlığı Osmanlı Arşivi) Dahiliye Nezareti Tesri-i Muamelat ve Islahat Komisyonu (DH. TMIK. S), 56/12, 12 Kasim 1904 (4 Ramazan 1322).

${ }^{15}$ BOA (Devlet Arşivleri Başkanlığı Osmanlı Arşivi) Dahiliye Nezareti Tesri-i Muamelat ve Islahat Komisyonu (DH. TMIK. S), 58/50, 22 Mayıs 1905 (17 Rebiülevvel 1323).
} 
teşebbüsleri esnasında mekâna verilen zararlar binayı daha da kötü hale getirmektedir. 1914 yılında gerçekleşen bir firar teşebbüsünde binanın menfezine ciddi zarar verilmiştir. Binanın fiziki olarak yetersizliğinin yanında bazı dönemlerde mahkûmlar tarafından binaya verilen bu gibi zararların giderilebilmesi için de bütçeye ihtiyaç duyulmaktadır. Yapılan tespitlerde mahkûmların gerçekleştirdiği bu eylem neticesinde yaklaşık altı yüz kırk sekiz kuruşluk bir masraf ortaya çıkmıştır. Gereken miktar Dahiliye ve Maliye Nezaretleri ile yapılan ve aylar süren yazışmaların ardından ancak temin edilebilmiştir. ${ }^{16}$ Yaşanan bu gelişmelerle birlikte yeni bir binanın yapılması hususundaki taleplerin ve yazışmaların 1910'lu yıllarda arttığı göze çarpmaktadır. 1911 yılında Canik Mutasarrıflığından kaleme alınan yazı ile bir kez daha Çarşamba'daki hapishanenin mahkûmlar için yeterli olmadığı ve genişletilmesine duyulan ihtiyaç açıkça vurgulanmıştır. ${ }^{17}$

Her ne kadar hapishane olarak kullanılmakta olan mevcut binada yapılması gereken birtakım tadilat için belirli dönemlerde bütçe temin edilebilse de yıllar geçmesine rağmen ekonomik nedenlerden ötürü Çarşamba'da yeni bir hapishane binasının inşaatına bir türlü başlanılamadığı anlaşılmaktadır. Ancak yerel yöneticiler ısrarla bu konu üzerinde durmaya devam etmişlerdir. ${ }^{18}$ Fakat Babıali yeni bir inşaata müsaade buyurmamış, mevcut yapının tamirat suretiyle daha iyi koşullara kavuşturulmasını uygun bulmuştur. $\mathrm{Bu}$ nedenle yapılması gereken tadilat ve tamirat için detaylı bir keşif çalışması yapılmıştır. Çalışmalar sonucunda Dahiliye Nezareti'nden beş bin altı yüz kuruşluk ödeneğin gönderilmesine izin verilmesi hususunda talepte bulunulmuştur. Ancak nezaret tarafından binada yapılacak tamiratın neler olduğu ve bunun için hangi kalemlere ne kadar para harcanacağının iletilmediği öne sürülerek ilk etapta bütçe talebi reddedilmiştir. ${ }^{19}$ Bunun üzerine yerel sorumlular öncelikle hapishanenin dış duvar inşaatı için gereken malzemeler üzerinde detaylı bir çalışma yapmış ve aşağıdaki tablo hazırlanarak ilgili makamlara sunulmuştur. ${ }^{20}$

\footnotetext{
${ }^{16}$ BOA (Devlet Arşivleri Başkanlığı Osmanlı Arşivi) Dahiliye Nezareti Mebani-i Emiriye-Hapishaneler Müdüriyeti Evrakı (DH. MB. HPS), 5/44, 20 Ocak 1914 (22 Safer 1332)

17 Samsun ve Bafra'da bulunan hapishanelerinin kapasitelerinin de yeterli olmadığı, bu nedenle onların da genişletilmeye ihtiyaçları olduğu aynı yazıda belirtilmektedir. BOA (Devlet Arşivleri Başkanlığı Osmanlı Arşivi) Dahiliye Nezareti Mebani-i Emiriye-Hapishaneler Müdüriyeti Evrakı (DH. MB. HPS), 143/23, 8 Nisan 1911 (26 Mart 1327)

${ }^{18} \mathrm{Bu}$ süreçte hapishaneler için gerekli bütçenin aktarılamaması pek çok vilayet ve kaza hapishanesi için geçerli bir durumdur. İhtiyaçlar her ne kadar elzem olsa da mali bütçenin mevcut koşullar içerisinde uygun olmaması başka yollara başvurulmasını gerekli kılmaktadır. Bu nedenle devlet yetkilileri de yeni inşaat veya tamirat için gereken miktarların yerelden karşılanmasını önermişlerdir. BOA (Devlet Arşivleri Başkanlı̆̆ Osmanlı Arşivi) Dahiliye Nezareti Tesri-i Muamelat ve Islahat Komisyonu (DH. TMIK. S), 21/16, 1 Ekim 1898 (15 Cemaziyelevvel 1316).

${ }^{19}$ BOA (Devlet Arşivleri Başkanlığı Osmanlı Arşivi) Dahiliye Nezareti Mebani-i Emiriye-Hapishaneler Müdüriyeti Evrakl (DH. MB. HPS), 124/3, 17 Ağustos 1918, (17 Ağustos 1334).

${ }^{20}$ Canik Sancağının şehir hapishanesinde de benzer bir ihtiyaç hasıl olmuş ve hapishanenin dış duvarının inşaatı için 1868 yılında merkezden talep edilen ödenen alınmıştır. Mehmet Yavuz Erler, "Karadeniz'de Avrupai Bir Kent Samsun (1865-1875)”, Karadeniz Tarihi Sempozyumu, Cilt:1, Trabzon 2007, s.550.
} 
Osmanlı Devleti'nde Hapishanelerin Islah Çalışmalarına Dair Bir İnceleme: Çarşamba Hapishanesi

Tablo 1: Çarșamba Hapishanesi Dıș Duvar İnşaatı İçin Kullanılacak Malzemelerin Cinsi, Miktarı ve Bedeli ${ }^{21}$

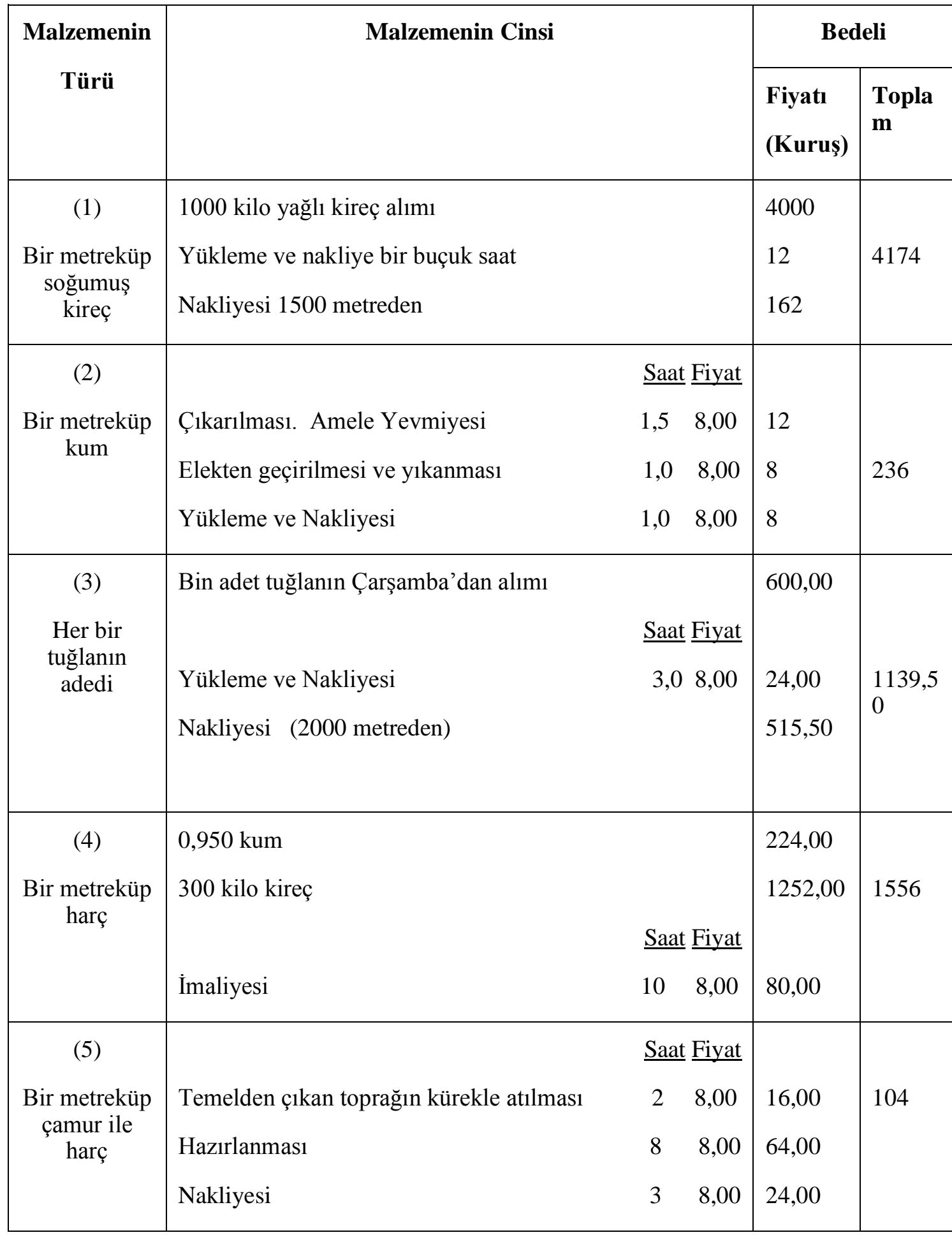

${ }^{21}$ BOA (Devlet Arşivleri Başkanlığı Osmanlı Arşivi) Dahiliye Nezareti Mebani-i Emiriye-Hapishaneler Müdüriyeti Evrakl (DH. MB. HPS), 124/3, 17 Ağustos 1918, (17 Ağustos 1334). 
Hakan Tan

\begin{tabular}{|c|c|c|c|c|c|}
\hline \multirow{2}{*}{$\begin{array}{c}\text { (6) } \\
\text { Bir metreküp } \\
\text { temel } \\
\text { kazılması }\end{array}$} & \multicolumn{3}{|c|}{$\underline{\text { Saat Fiyat }}$} & \multirow[b]{2}{*}{24} & \multirow[b]{2}{*}{24} \\
\hline & Kazmacı yevmiyesi & 2 & 12 & & \\
\hline (7) & & $\underline{\mathrm{Saa}}$ & Fiyat & & \multirow{3}{*}{48,00} \\
\hline \multirow{2}{*}{$\begin{array}{l}\text { Eski duvarın } \\
\text { bir metreküp } \\
\text { sökülmesi }\end{array}$} & Sökülmesi & 2 & 8 & 16,00 & \\
\hline & Seçilmesi ve Temizlenmesi & 4 & 8 & 32,00 & \\
\hline (8) & & $\underline{\text { Saa }}$ & Fiyat & & \multirow{5}{*}{210,60} \\
\hline \multirow{4}{*}{$\begin{array}{l}\text { Çamurla bir } \\
\text { metreküp taş } \\
\text { duvar }\end{array}$} & 0,40 Çamur & & 104 & 41,60 & \\
\hline & Taşın temizlenmesi & 4 & 8,00 & 32,00 & \\
\hline & Duvarın yapılması duvarc1 yevmiyesi & 5 & 20 & 100,00 & \\
\hline & Duvarın yapılması amele yevmiyesi & 5 & 8,00 & 40,00 & \\
\hline \multirow{4}{*}{$\begin{array}{c}\text { (9) } \\
\text { Tuğladan bir } \\
\text { metreküp } \\
\text { çamurla } \\
\text { duvar inşası }\end{array}$} & & \multicolumn{2}{|c|}{$\underline{\text { Saat Fiyat }}$} & \multirow{4}{*}{$\begin{array}{l}23,00 \\
100,00 \\
40,00\end{array}$} & \multirow{4}{*}{163,00} \\
\hline & $\begin{array}{l}\text { Mevcut tuğla } 0,22 \text { metreküp } \\
\text { toprak harc1 }\end{array}$ & & & & \\
\hline & Ustalık, duvarc1 yevmiyesi & 5 & 20 & & \\
\hline & Ustalık, amele yevmiyesi & 5 & 8 & & \\
\hline$(10)$ & & $\underline{\mathrm{Saa}}$ & Fiyat & & \multirow{5}{*}{543,00} \\
\hline \multirow{4}{*}{$\begin{array}{l}\text { Tuğla ile bir } \\
\text { metreküp } \\
\text { çamur } \\
\text { harciyla } \\
\text { duvar inşası }\end{array}$} & Tuğla satın alımı (333 adet) & & 1140 & 380,00 & \\
\hline & 0.22 metreküp toprak harç & & 104 & 23,00 & \\
\hline & Ustalık, duvarc1 yevmiyesi & 5 & 20 & 100,00 & \\
\hline & Ustalık, amele yevmiyesi & 5 & 8 & 40,00 & \\
\hline (11) & & $\underline{\text { Saa }}$ & Fiyat & & \multirow[b]{3}{*}{863,00} \\
\hline \multirow{2}{*}{$\begin{array}{l}\text { Tuğla ile bir } \\
\text { metreküp } \\
\text { kireç } \\
\text { dökümü }\end{array}$} & 333 adet tuğla & & 1140 & 380 & \\
\hline & 0,22 metreküp kireç harc1 & & 1556 & 343 & \\
\hline
\end{tabular}


Osmanlı Devleti'nde Hapishanelerin Islah Çalışmalarına Dair Bir İnceleme: Çarşamba Hapishanesi

\begin{tabular}{|c|lrr|l|l|}
\hline $\begin{array}{c}\text { harcıyla } \\
\text { duvar inşası }\end{array}$ & Ustalık, duvarcı yevmiyesi & 5 & 20 & 100 & \\
& Ustalık, amele yevmiyesi & 5 & 8 & 40 & \\
\hline \multirow{2}{*}{$(12)$} & & $\underline{\text { Saat }} \underline{\text { Fiyat }}$ & & \\
& Duvarın temizlenmesi & 0,50 & 8 & 4,00 & \\
& O.020 metreküp harç & 1556 & 31,00 & 77,00 \\
& Ustalık, duvarcı yevmiyesi & 1,50 & 20 & 30,00 & \\
& Ustalık, amele yevmiyesi & 1,50 & 8 & 12,00 & \\
& & & & &
\end{tabular}

Tablodan açıkça görüleceği üzere Çarşamba hapishanesinin dış duvarının inşaatı için gerekli malzemeler üzerinde detaylı bir çalışma yapılmıştır. İhtiyaç duyulan malzemeler on iki kalemde ele alınmış ve bunlar arasında kum, kireç, tuğla, harç gibi ürünler bulunmaktadır. Her bir ürünün nerede ve ne şekilde kullanılacağının da açıklandığ 1 tabloda malzemelerden hangi miktarlarda gerekli olduğu bilgisi de özellikle belirtilmiştir. İnşaat esnasında kullanılacak malzemelerin miktarlarıyla birlikte mali olarak değerleri de karşılarında gösterilmiştir. Ancak yapılacak işin boyutları ve ciddiyeti bu ürünlerin işlenmesi ve kullanılması esnasında kendini göstermektedir. Öyle ki, iş yalnızca ürünlerin mali karşılıklarının hesaplanması ve satın alınmasıyla bitmemekte, bu ürünlerin bulundukları yerden inşaat alanına götürülmeleri sürecinde nakliye, yükleme ve indirme gibi aşamaları da içermektedir. Nakliyenin hangi mesafeden yapılacağının dahi kayıt altına alındığı tabloda her birinin fiyatı ayrı ayrı kaydedilmiştir.

Söz konusu tabloda dikkat çeken bir başka ayrıntı temin edilen ürünlerin kullanımı esnasında gerekli olan zaman ve bu zaman diliminde harcanacak beden gücünün de hesaba katılmış olmasıdır. Ayrıca her bir iş için saat ve ücret bilgileri belirtilmiş ve yapılacak iş için gerekli zaman ve ücret belirlenmiştir. Bunun yanı sıra bu işlerde çalışacak amele, kazmacı ve duvarcı ustalarının harcayacakları zaman ve alacakları yevmiyeleri gösterilmiştir. Mevcut verilerden anlaşıldığı kadarıyla da duvarcı ustalarının aldıkları yevmiye, kazmacı yevmiyesinin yaklaşık bir buçuk katı, amele yevmiyesinin ise iki buçuk katıdır. Tabloda detaylıca verilen ihtiyaç listesi haricinde hapishane duvarının planı da hazırlanmış ve gönderilmiştir.

Hapishane Reformu sürecinde devletin içinde bulunduğu iktisadi ve siyasi durum memleketin birçok yerinde ve hemen hemen aynı anda başlayan hapishanelerin 1slahı hususundaki çalışmaları kesintiye uğratmıştır. Bu dönemde yapılan yazışmaların yoğunluğu ve taleplerin istenilen oranlarda karşılanamamış olması bunun en önemli kanıtlarındandır. Aynı zamanda taşradan gelen taleplere ilişkin merkezi yönetimin yapılacak inşaat ve tamirat öncesinde keşif çalışmalarını en ince ayrıntısına kadar incelemesi ve eksikliklerin giderilmesi konusundaki uyarıları eldeki kaynakların verimli bir șekilde kullanılmak istenmesine ișaret etmektedir. Bu noktada Çarşamba hapishanesi dahilinde yürütülmekte olan iyileştirme çalışmalarına mali destek sağlanması konusunda aynı titizliğin 1919 yılında hapishanenin iç kısmında yapılması planlanan tamiratlar esnasında da devam ettiği anlaşılmıştır.

Hapishanenin döşeme tahtaları, helaları, demir parmaklıkları gibi kısımlarının tamiratı için gereken miktarın temin edilebilmesi adına yürütülen çalışmalar yaklaşık bir sene sürmüştür. İhtiyaç duyulan meblağın bir kısmının gönderildiği ancak tamiratın tamamının henüz bitirilemediği ve kullanılacak ahşap malzeme ölçülerinin de belirtilmemiş olmasından keşif çalışmalarının tekrar yapılması konusunda Canik Mutasarrıflığına bilgi verilmiştir. Buna 
istinaden tamirat için kullanılacak malzemelerin detaylı ölçüleri aşağıdaki haliyle hazırlanarak ilgili birimlere sunulmuştur.

Tablo 2: İnşaat İçin Gerekli Olan Malzeme Listesi ${ }^{22}$

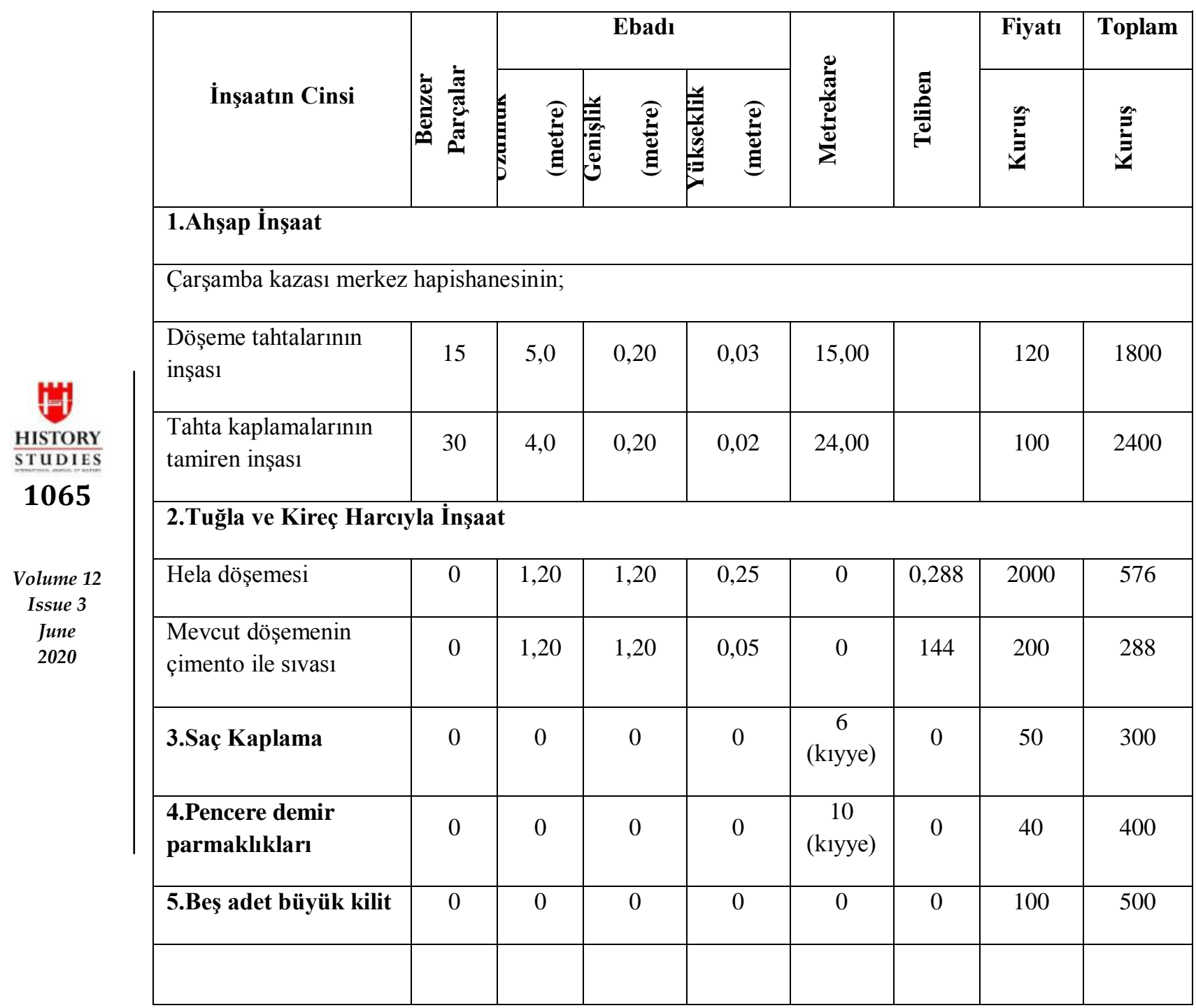

Tabloda belirtilen malzemeler için ihtiyaç duyulan miktarla ilgili Canik Mutasarrıflığından on bin beş yüz seksen iki kuruş talep edilmiştir. Her ne kadar belirtilen masraflar için istenilen miktar bu olsa da merkezden gelen cevapta hela döşemelerine ait ölçü birimi fiyatındaki durumdan dolayı dört bin üç yüz on sekiz kuruş kesinti yapılmış ve altı bin altı yüz altmış dört kuruş olarak tashih edilmiştir.

${ }^{22}$ BOA (Devlet Arşivleri Başkanlığı Osmanlı Arşivi) Dahiliye Nezareti Mebani-i Emiriye-Hapishaneler Müdüriyeti Evrakı (DH. MB. HPS), 16/49, 24 Ağustos 1919, (24 Ağustos 1335).

${ }^{23}$ BOA (Devlet Arşivleri Başkanlığı Osmanlı Arşivi) Dahiliye Nezareti Mebani-i Emiriye-Hapishaneler Müdüriyeti Evrakı (DH. MB. HPS), 16/49, 21 Eylül 1919, (21 Eylül 1335). 
Yukarıdaki mevcut tablolar ve bilgiler 1şı̆̆ında Hapishane Reformu sürecinden önce Çarşamba hapishanesinin mahkûmlar için gerekli olan sağlık koşullarını karşılamaktan oldukça uzak olduğu anlaşılmaktadır. Bu noktada hapishanenin iç mekanının tamiratı ve dış duvarının inşaatı için uzun süren yazışmaların yapıldığı ve yoğun bir bürokrasinin işlediği görülmektedir. Yapılması planlanan inşaat ve tamiratla ilgili öncesinde oldukça detaylı keşif raporları hazırlanmakta bu raporların incelenmesi nihayetinde ödenek verilip verilmemesi gündeme gelmekteydi. Çarşamba hapishanesinin fiziki şartlarının 1slah edilebilmesi için de uzun yıllar çalışıldığ 1 anlaşılmaktadır. Ancak hapishanede gerçekleştirilen tamir işlemleri neticesinde XX. yüzyılın başlarında Çarşamba hapishanesinin çevredeki diğer birçok hapishaneden daha iyi durumda olduğunu söylemek de mümkündür. ${ }^{24}$

\section{2- Hapishanedeki Mahkûm ve Tutuklular}

Çarşamba hapishanesinde kabahat, cünha ve cinayet gibi suç türlerinden farklı yaş, cinsiyet, meslek ve din gruplarına mensup mahkûm ve tutuklular mevcuttur. ${ }^{25}$ Yukarıda değinildiği gibi hapishanenin fiziki yapısının daha iyi bir hale getirilmesi hususundaki çalışmalar esasında burada cezalarını çekmekte olan kişilerin daha iyi koşullar altında yaşamaları anlamı taşımaktaydı. Çalışmanın bu bölümünde hapishanedeki mahkûm ve tutuklulara dair sayısal bilgilerin yanında kişilerin gündelik yaşamları hakkında tespitler yansıtılarak Hapishane Reformu sürecinde 1slah çalışmalarının bir diğer yönü ortaya koyulacaktır.

Osmanlı Devleti diğer ülkelerde de uygulandığı gibi hapishanelere dair aylık ve yıllık istatistik cetvelleri hazırlamaktayd1. Bu konu 1890'daki Petersburg Hapishaneler Kongresi'nde de ele alınan hususlardan biriydi. ${ }^{26}$ Burada yapılan müzakereler sonucunda kongreye katılan her ülkenin genel bir hapishane istatistiği düzenlemesi ve bir sonraki kongrede tekrar ele alınması kararlaştırılmıştı. ${ }^{27}$ Tutulan bu istatistikler sayesinde hapishanelerde bulunan kişilere dair veriler elde etmek mümkün olabilmektedir. Bu noktada Çarşamba hapishanesi özelinde hazırlanmış ve tespit edebildiğimiz bu cetvellerden hapishanedeki mahkûmların sayısı tespit

\footnotetext{
${ }^{24}$ Tanin gazetesi muhabiri Ahmet Şerif Bey Anadolu'nun muhtelif yerlerine yaptı̆̆ gezilerdeki izlenimlerini “Anadolu'da Tanin” adıyla Tanin gazetesinde yayınlamıştır. Ahmet Şerif gezdiği yerlerde özellikle hapishaneleri gözlemlemiş ve yazılarında buralara dair görüşlerini aktarmıştır. Gezmiş olduğu birçok hapishanenin kötü durumda olduğunu belirten Şerif, sınırlı da olsa bazı hapishaneler hakkında olumlu yorumlarda bulunmuştur. Bunlardan birisi de Çarşamba hapishanesidir. Hapishanenin benzerlerine göre pek düzenli ve iyi olduğundan bahsederken, ziyaretçilerin hapishane olarak kullanılan bu daireleri sevinç ve hoşlanma duygusuyla gezebileceğini de eklemektedir. Bkn: Ahmet Ali Gazel, "Tanin Muhabiri Ahmet Şerif Beyin Notlarında Osmanlı Hapishaneleri”, Hapishane Kitabı, Ed. Emine Gürsoy Naskali, Hilal Oytun Altun, Kitabevi Yayınları, İstanbul 2018, s.150.

${ }^{25}$ Cünha ve kabahat suçu, memurlara hakaret etme, mahpus kaçırmak, pasaportta sahtekarlık yapmak, darp, zina, sarkıntılık, çocuk ve kız kaçırmak, yalancı şahitlik, insanlara hakaret ve iftira, hırsızlık, emniyeti suiistimal ve alınan borcun geri ödenmemesi gibi eylemleri kapsamaktadır. Cinayet ise, yol kesmek ve zimmete para geçirmek, adam öldürmek, yaralama, cebren zina, zorla kız kaçırmak, resmi evrakta sahtecilik yapmak, kundakçılık, şiddet yolu ile hırsızlık yapmak, silah kaçakçılığı gibi suçları kapsamaktadır. Osman Köse, "Canik’te Asayiş (1911-1914)”, Samsun Araştırmaları, Ed. Cevdet Yılmaz, Samsun Büyükşehir Belediyesi Kültür Yayınları, Samsun 2013, s.227.

${ }^{26}$ Kongre, İngiltere, Avusturya, Belçika, Danimarka, İspanya, Fransa, Yunanistan, İtalya, Japonya, Norveç, İsveç, Amerika ve Osmanlı Devleti'nin de katılımıla 1890 senesinde Petersburg'da gerçekleşmiştir. Osmanlı Devleti adına kongreye, ceza işleri müdür Celal Bey katılmıştır. Celal Bey’in görevlendirilmesinde kendisinin yabancı dil bilmesi de etkili olmuştur. Kongrenin yaklaştı̆̆ 1 tarihlerde kendisine gidiş, dönüş ve orada yapacağı masraflar için 300 kuruş harcirah verilmesi de uygun görülmüştür. Fatmagül Demirel, "1890 Petersburg Hapishaneler Kongresi”, Toplumsal Tarih, C.15, S.89 (Mayıs 2001), s.11,13.; BOA (Devlet Arşivleri Başkanlığı Osmanlı Arşivi), Meclis-i Vükela Mazbataları (MV.), 48/55, 30 Ekim 1899 (5 Rebüülevvel 1307).; BOA (Devlet Arşivleri Başkanlığı Osmanlı Arşivi), İrade Dahiliye (İ.DH.), 1176/91920, 18 Nisan 1890 (27 Şaban 1307).

${ }^{27}$ Demirel, a.g.m., s.13,14.;
} 
edilebilmektedir. Bu hususta tespit edebildiğimiz ve detayları aşağıdaki tabloda yer alan ilk istatistiki bilgiler 1909 y1lına aittir.

Tablo 3: 1-15 Kanun-ı Evvel 1325 Tarihleri Arasında Hapishaneye Giren ve Çıkan Mahpusların Cetveli ${ }^{28}$

\begin{tabular}{|c|c|c|c|c|c|c|c|c|c|c|}
\hline & \multicolumn{3}{|c|}{$\begin{array}{c}\text { Cinayetle Mahkûm ve } \\
\text { Mahpus }\end{array}$} & \multicolumn{3}{|c|}{$\begin{array}{l}\text { Cünha ve Kabahat ile } \\
\text { Mahkûm ve Mahpus }\end{array}$} & \multicolumn{3}{|c|}{$\begin{array}{l}\text { Borçlarından dolayı } \\
\text { Mahkûm ve Mahpus }\end{array}$} & \multirow[t]{2}{*}{ Açıklama } \\
\hline \multirow{3}{*}{$\begin{array}{c}\begin{array}{c}\text { Uy } \\
\text { HISTORY }\end{array} \\
\frac{1067}{\text { STUDIES }}\end{array}$} & 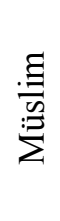 & 弯 & $\frac{\tilde{E}}{\frac{\tilde{J}}{2}}$ & 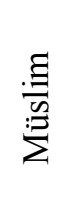 & : & $\frac{\tilde{J}}{2}$ & $\begin{array}{l}: \Xi \\
: \stackrel{\Xi}{\Sigma} \\
: \bar{z}\end{array}$ & 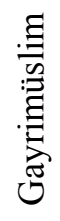 & $\frac{\Xi}{\frac{\Xi}{2}}$ & \\
\hline & - & - & - & - & 3 & 3 & - & - & - & $\begin{array}{c}1 \text { Kanun-1 } \\
\text { Evvel } \\
1325 \\
\text { tarihinde } \\
\text { mevcut }\end{array}$ \\
\hline & - & - & - & 6 & - & 6 & - & - & - & $\begin{array}{c}1-15 \\
\text { Kanun-1 } \\
\text { Evvel } \\
\text { arasinda } \\
\text { gelen }\end{array}$ \\
\hline \multirow{3}{*}{$\begin{array}{c}\text { Volume } 12 \\
\text { Issue } 3 \\
\text { June } \\
2020\end{array}$} & - & - & - & 6 & 3 & 9 & - & - & - & Toplam \\
\hline & - & - & - & 2 & - & 2 & - & - & - & $\begin{array}{c}1-15 \\
\text { Kanun-1 } \\
\text { Evvel } \\
\text { arasında } \\
\text { çıan }\end{array}$ \\
\hline & - & - & - & 4 & 3 & 7 & - & - & - & $\begin{array}{c}16 \text { Kanun- } \\
1 \text { Evvel } \\
1325 \\
\text { tarihinde } \\
\text { mevcut }\end{array}$ \\
\hline
\end{tabular}

Tablo; cinayet, cünha ve kabahat ve borçlarından dolayı hapishanede bulunanlar olmak üzere üç ana kategori baz alınarak hazırlanmıştır. Buna göre hapishanede cinayet suçundan ve borçtan ötürü herhangi bir kimse bulunmamaktadır. Cünha ve kabahat suçundan ise 1 Kanun-1

${ }^{28}$ BOA (Devlet Arşivleri Başkanlığı Osmanlı Arşivi) Dahiliye Nezareti Mebani-i Emiriye-Hapishaneler Müdüriyeti Evrakl (DH. MB. HPS), 142/37, 30 Ocak 1910, (17 Kanun-1 Sani 1325). 
Evvel'de 3 gayrimüslim mevcut iken, ayın 16'sina kadar 6 müslim kimsenin de gelmesiyle birlikte toplam 9 kişi bulunmaktadır. Ancak bu tarihler arasında aynı zamanda 2 müslim kişi hapishaneden çıkmış ve toplam sayı 4'ü müslim, 3'ü gayrimüslim olmak üzere 7 kişiden ibarettir.

Aşağıdaki tablo ise bir sonraki aya dair bilgileri ihtiva etmektedir:

\section{Tablo 4: 16-30 Kanun-ı Evvel 1325 Tarihleri Arasında Giren ve Çıkan Mahpusların Cetveli ${ }^{29}$}

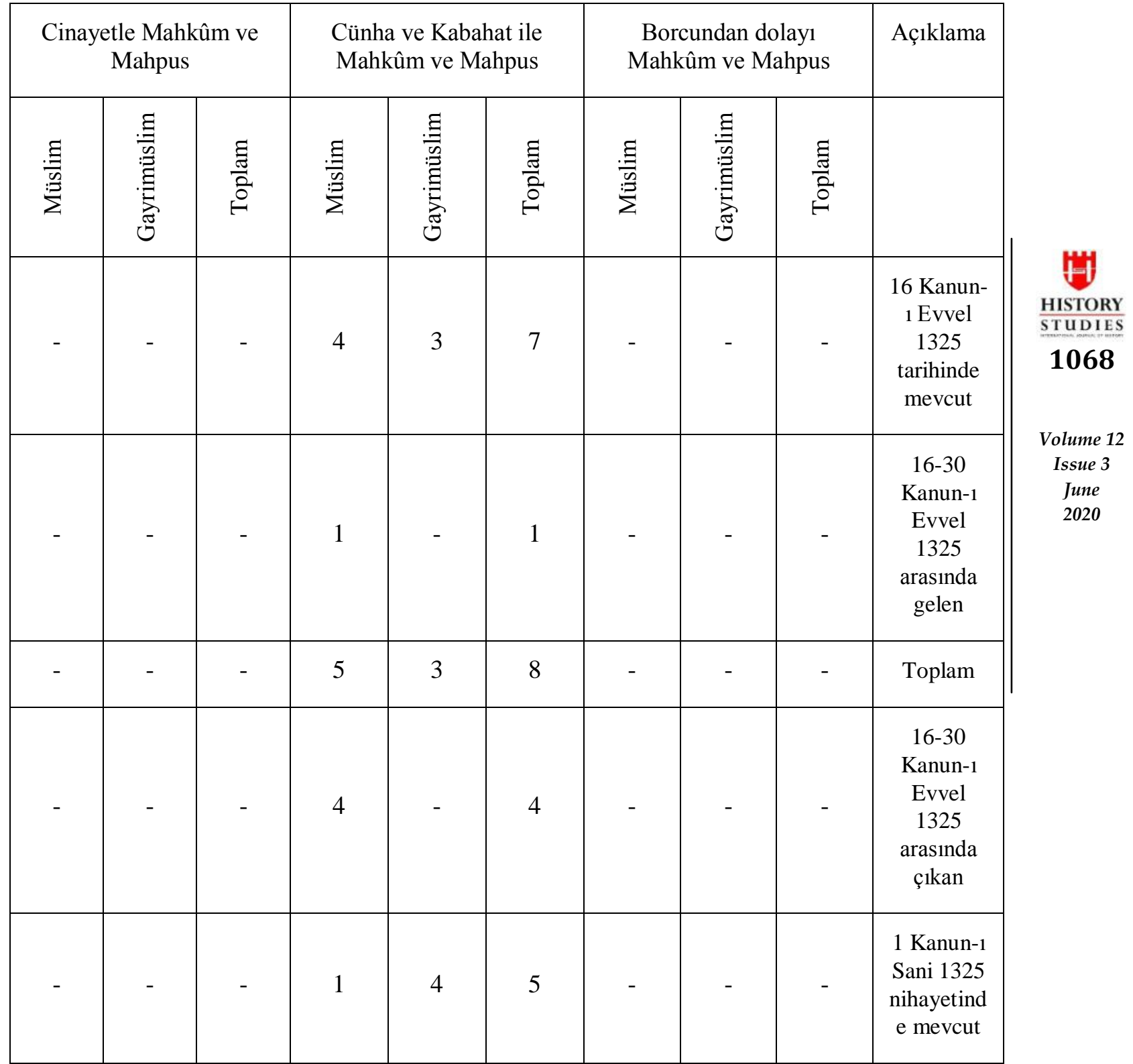

${ }^{29}$ BOA (Devlet Arşivleri Başkanlığ ${ }_{1}$ Osmanlı Arşivi) Dahiliye Nezareti Mebani-i Emiriye-Hapishaneler Müdüriyeti Evrakl (DH. MB. HPS), 142/37, 30 Ocak 1910, (17 Kanun-1 Sani 1325). 
Bir önceki tablonun devamı niteliğindeki bu yoklama cetvelinde halihazırda hapishanede bulunan 7 kişiye ilave olarak 1 kişinin daha hapishaneye geldiği ve toplam mevcudun 8 kişi olduğu anlaşılmaktadır. 1 Kanun-1 Sani tarihinde ise 1 müslim ve 4 gayrimüslim olmak üzere toplamda 5 kişinin mevcut olduğu görülmektedir.

1911 senesine ait yıllık olarak hazırlanan hapishane yoklama cetvelinin bir öncekilerden daha farklı olarak dört kategoride hazırlandığı ve aylara göre düzenlendiği anlaşılmaktadır. Aşağıda detayları verilen tablo ve söz konusu yıl içerisinde hapishanede bulunan kişilere dair detayları şu şekildedir:

Tablo 5: 1911 Senesine Ait Hapishane Yoklama Cetveli ${ }^{30}$

Volume 12

Issue 3

June

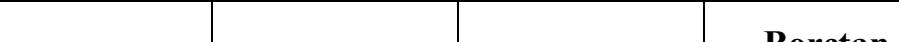

\begin{tabular}{|c|c|c|c|c|c|}
\hline Aylar & $\begin{array}{c}\text { Cinayetle } \\
\text { mahkûm } \\
\text { olanlar }\end{array}$ & $\begin{array}{c}\text { Cünha ile } \\
\text { mahkûm } \\
\text { olanlar }\end{array}$ & $\begin{array}{c}\text { Kabahatle } \\
\text { mahkûm } \\
\text { olanlar }\end{array}$ & $\begin{array}{c}\text { Borçtan } \\
\text { dolayı } \\
\text { mahkûm } \\
\text { olanlar }\end{array}$ & Toplam \\
\hline Mart & 6 & 12 & 20 & - & 38 \\
\hline Nisan & - & - & - & - & - \\
\hline Mayıs & - & 4 & 8 & - & 12 \\
\hline Haziran & - & - & - & - & - \\
\hline Temmuz & - & - & - & - & - \\
\hline Ağustos & - & 2 & 5 & - & 7 \\
\hline Eylül & - & - & - & - & - \\
\hline $\begin{array}{c}\text { Teşrin-i } \\
\text { Evvel }\end{array}$ & - & - & - & - & - \\
\hline $\begin{array}{c}\text { Teşrin-i } \\
\text { Sani }\end{array}$ & - & 1 & 4 & - & 5 \\
\hline $\begin{array}{c}\text { Kanun-ı } \\
\text { Evvel }\end{array}$ & - & - & - & - & - \\
\hline$\underset{\text { Kanun-ı }}{\text { Sani }}$ & - & 4 & 8 & - & 12 \\
\hline
\end{tabular}

${ }^{30}$ BOA (Devlet Arşivleri Başkanlığı Osmanlı Arşivi) Dahiliye Nezareti Mebani-i Emiriye-Hapishaneler Müdüriyeti Müteferrik Evrakı (DH. MB. HPS. M), 5/1, 21 Mayıs 1912, (4 Cemaziyelahir 1330). 
Osmanlı Devleti'nde Hapishanelerin Islah Çalışmalarına Dair Bir İnceleme: Çarşamba Hapishanesi

\begin{tabular}{|c|c|c|c|c|c|}
\hline Şubat & - & 3 & - & - & 3 \\
\hline Toplam & 6 & 26 & 45 & - & 77 \\
\hline
\end{tabular}

1911 yllına ait verilerin kaydedildiği bu cetvelde toplam 77 kişinin bulunduğu anlaşılmaktadır. En fazla mahkûmun ise kabahat suçundan ceza aldığı, bunu cünha ve cinayet suçlularının takip ettiği görülmektedir. Ayrıca aynı ay içerisinde en fazla sayıda mahkûmun 20 'sinin kabahat, 12'sinin cünha ve 6'sının da cinayet suçundan ceza aldığı dikkat çekmektedir.

Tablonun ekinde yer alan bilgilerden hapishanede bulunan kişilere dair daha fazla detaylı bilgilere ulaşmak mümkündür. ${ }^{31}$ Buna göre; 25 kişi adam vurma ve yaralama suçlarından hapishanededirler. 22 kişi ise sirkat yani hırsızlık suçundan hapishanede tutulmaktadır. 5'i erkek 1'i kadın olmak üzere 6 kişinin de kasten adam öldürme suçundan hükümlü oldukları tespit edilebilmektedir. Hapishanedeki diğer kişilerin ise yine farklı suçlardan dolayı hapishanede tutuldukları anlaşılmaktadır.

Adam yaralama ve vurma suçundan hüküm alan toplam 25 kişinin mesleki dağılımları incelendiğinde 22'sinin zirai işlerler uğraştığ 1 , 2'sinin esnaf ve 1'inin de amele olduğu anlaşılmaktadır. Yine bu 25 kişiden 7'si yirmi dört saatten bir haftaya kadar, on biri bir haftadan bir aya kadar, dördü bir aydan üç aya kadar ve üçü de üç aydan altı aya kadar ceza almışlardır. Söz konusu kimselerin 12'si bekar, 8'i çocuklu ve 5'i de çocuksuz kişilerdir.

Toplam sayı üzerinden istatistiki bilgiler incelendiğinde ise erkek mahkûmlardan 42'si bekar, 22'si çocuklu, 12'si ise çocuksuz bireylerdir. Kasten adam öldürme suçundan hapishanede bulunan tek kadın hükümlünün de çocuksuz bir kimse olduğu tespit edilmiştir. Yine toplam sayı üzerinden mahkûmların mesleki dağılımları incelendiğinde farklı gruplara ait kişilerin bulunduğu anlaşılmaktadır. En fazla sayıyla ilk sırada çiftçiler yer almaktadır. Buna göre; 77 kişiden 48'i zirai işlerler uğraşırken, 6'sı amelelik yapmakta, 21'i işsiz ve 2 kişi de esnaflık yapmaktadır. 77 kişilik yekûn içerisinden 71 kişinin okuma yazması yokken ancak 6 kişi okuma yazma bilmektedir.

Mahkûmların yaş grupları ele alındığında hapishanede 14 yaşından küçük kimsenin bulunmadığı anlaşılmaktadır. 14 ile 20 yaş arasında 10 kişi, 20 ile 30 yaş arasında 1'i kadın

\footnotetext{
${ }^{31} \mathrm{Bu}$ tarihte hazırlanan yoklama cetvelinin daha öncekilerden çok daha farklı ve detaylı olduğu anlaşılmaktadır. Osmanlı Devleti hapishaneleri konusunda birçok çalışmaları bulunan Kent Schull bu durumun İttihat ve Terakki yönetiminin hapishanelerde bulunanlar hakkında detaylı bilgilere ulaşmak istemesinden kaynaklandığını savunmaktadır. 1909 ve 1910 yıllarına ait yoklama cetvelleri daha sade bilgileri içermekteydi. Ancak detaylı bir şekilde hapishane istatistiklerinin tutulmaya başlaması 1910'lu yıllardan sonra gerçekleşmeye başlamıştır. Özellikle 1912 yılında hapishaneler hakkında gerçekleştirilen çalışma bu konudaki en detaylı çalışmalardan birisidir. Bu çalışmada mahkûmların sadece sayısı değil, aynı zamanda yaş, cinsiyet, medeni hal, etnik köken, okuryazarlık, eğitim düzeyleri, mesleki durumları, hüküm giydikleri suçtan yargılanıp yargılanmadıkları, çocukları olup olmadığı, ne işle meşgul oldukları, ne suç işledikleri ve hangi tarihte mahkûm edildikleri gibi bilgiler hapishane yönetimlerinden talep edilmekteydi. Mahkûmların işledikleri suçlar ve sosyoekonomik statüleriyle ilgili diğer soruların cevapları da cetvel halinde istenmekteydi. Bu kategorilere, mahkûmun bir öğretmen, doktor, tüccar, sarraf, banker, toprak sahibi, esnaf, çiftçi, gemi kaptanı, mürettebat, uşak ya da devlet memuru mu yoksa işsiz mi olduğu bilgileri de dahil edilmişti. Kent Schull, "Tutuklu Sayımı: Jön Türklerin Sistematik Bir Şekilde Hapishane İstatistikleri Toplama Çalışmaları ve Bunların 1911-1918 Hapishane Reformu Üzerine Etkileri”, Osmanlı'da Asayiş Suç ve Ceza, 18. 20. Yüzyıllar, Der. Noémi Levy, Alexandre Toumarkine, Tarih Vakfı Yurt Yayınları, İstanbul 2008, s.212,228.
} 
olmak üzere 32 kişi, 30 ile 40 aralı̆̆ında 33 kişi, 40 ile 50 yaş arasında kimse bulunmazken 50 ile 60 yaş aralığında 2 kişi mevcuttur. ${ }^{32}$

Yukarıda verilen bilgiler aşağıda gösterilen grafiklerden de takip edilebilmektedir:

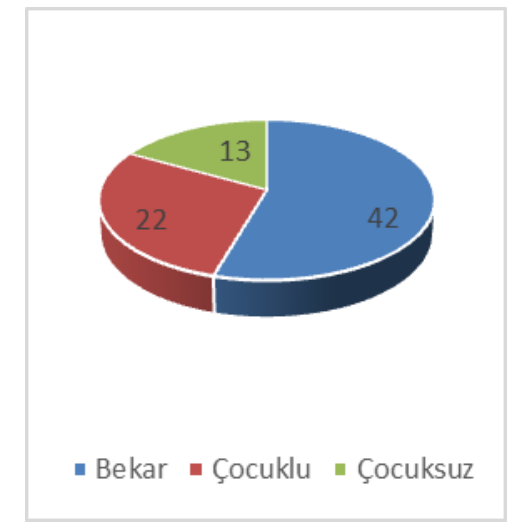

Grafik 1: Mahkûmların Medeni Durumu HISTORY STUDIES

1071

Volume 12

Issue 3

June

2020

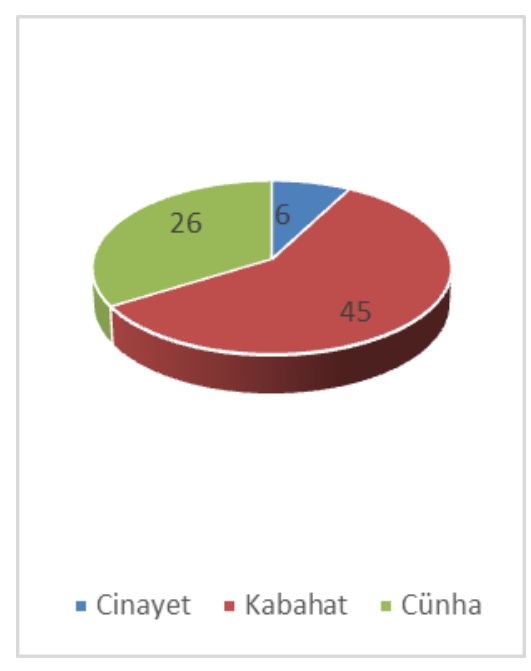

Grafik 3: Mahkûmların Suç Dağılımı

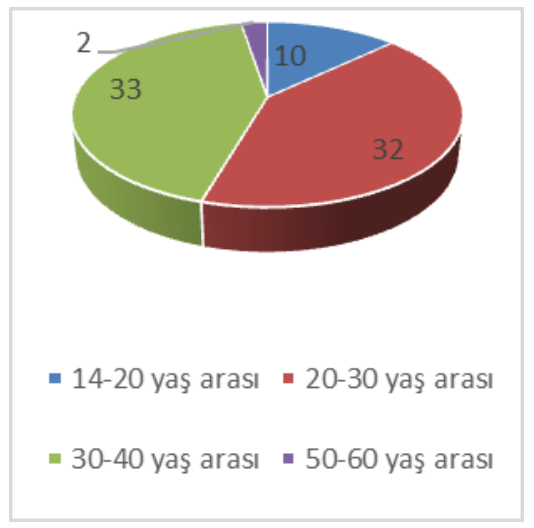

Grafik 2: Mahkûmların Yaş Dağılımı

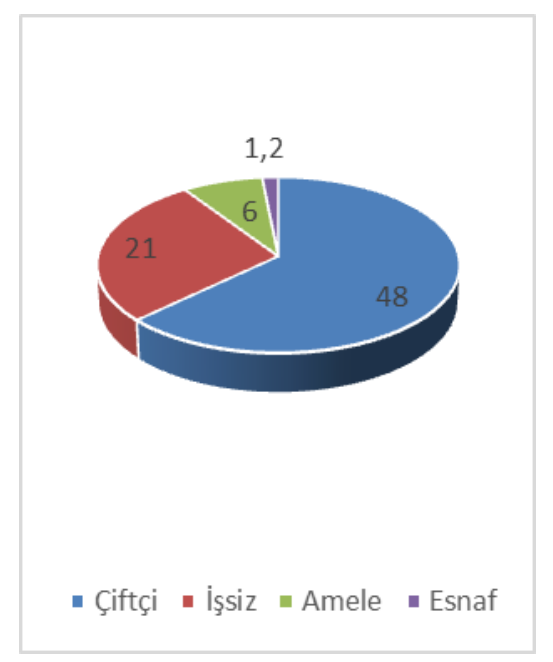

Grafik 4: Mahkûmların Mesleki Dağılımı

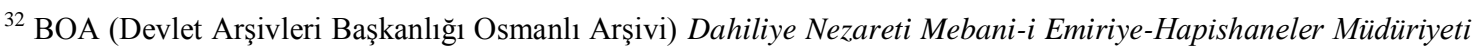
Müteferrik Evrakı (DH. MB. HPS. M), 5/1, 21 Mayıs 1912, (4 Cumaziyel Ahir 1330); Köse, a.g.m., s.241-242.
} 


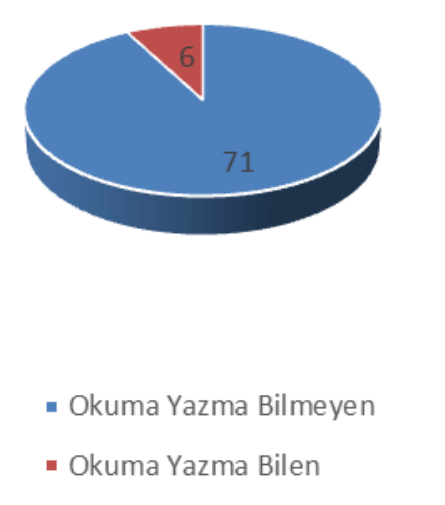

Grafik 5: Mahkûmların Eğitim Durumu

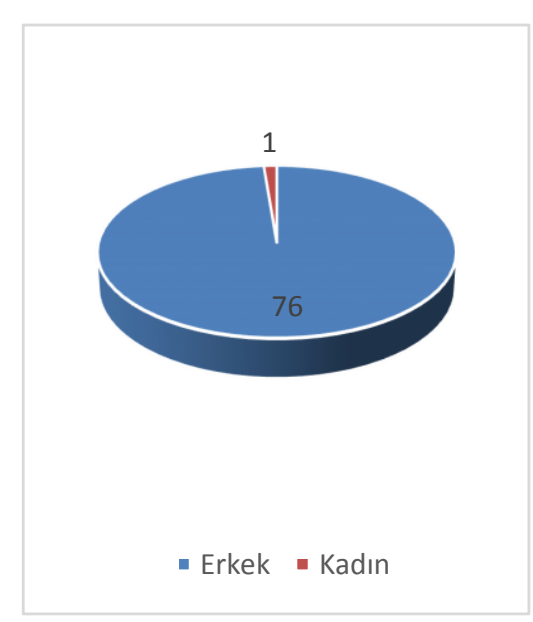

Grafik 6: Mahkûmların Cinsiyet Dağılımı

1911 yılının ardından Çarşamba hapishanesine dair tespit edebildiğimiz yoklama cetveli 1915 tarihlidir. Aşağıda detaylarına yer verilen cetvelde dört aylık süre içerisinde hapishanede bulunan kişilere ait veriler yer almaktadır.

Tablo 6: 1915 Yılı Çarşamba Hapishanesi'nin Dört Aylık Yoklama Cetveli ${ }^{33}$

\begin{tabular}{|c|c|c|c|c|c|c|c|}
\hline \multirow[t]{2}{*}{ Suçun Türü } & \multicolumn{3}{|c|}{ Mahkûmun Miktarı } & Açıklama & \multicolumn{3}{|c|}{ Mevkufin Miktarı } \\
\hline & Erkek & Kadin & Toplam & \multirow{5}{*}{$\begin{array}{c}1331 \text { senesi Mart } \\
\text { ayı 1. Gün } \\
\text { yoklamasında; } \\
\text { Teşrin-i Sani, } \\
\text { Kanun-1 Evvel, } \\
\text { Kanun-1 Sani ve } \\
\text { Şubat aylarını } \\
\text { kapsayan dört aylık } \\
\text { yoklamadır. }\end{array}$} & Erkek & Kadin & $\begin{array}{c}\text { Topla } \\
\text { m }\end{array}$ \\
\hline Cinayet & 16 & - & 16 & & 85 & 4 & 89 \\
\hline Cünha & 45 & - & 45 & & - & - & - \\
\hline Kabahat & - & - & - & & - & - & - \\
\hline Toplam & 61 & - & 61 & & - & - & - \\
\hline
\end{tabular}

Volume 12

Söz konusu tabloda cünha ve cinayet suçlarının ön plana çıtı̆̆g anlaşılmaktadır. Cinayet suçundan mahkûm olanların sayısı 16 iken aynı suçtan tutuklu bulunanların sayısı 85 erkek, 4 kadın olmak üzere toplam 89 kişidir. Cünha suçundan mahkûm olanların sayısı ise 45 kişi olarak tabloya işlenmiştir. Bu dört aylık süre zarfında kabahat suçundan hapishanede bulunanlara dair herhangi bir veri bulunmamaktadır.

\footnotetext{
${ }^{33}$ BOA (Devlet Arşivleri Başkanlığı Osmanlı Arşivi) Dahiliye Nezareti Mebani-i Emiriye-Hapishaneler Müdüriyeti Müteferrik Evrakı (DH. MB. HPS. M), 20/96, 19 Nisan 1915, (6 Nisan 1331).
} 
1917 yılına ait aşağıda verilen tabloda ise hapishanede bulunan kişi sayısında bir önceki verilere nazaran azalma olduğu anlaşılmadır.

Tablo 7: 1917 Yılı Çarşamba Kazası Tevkifhane ve Hapishanesi Mevcudu ${ }^{34}$

\begin{tabular}{|c|c|c|c|}
\hline Mevcudun Adedi & Erkek & Kadın & $\begin{array}{c}\text { Henüz 18 Yaşında } \\
\text { olmayan tutuklular }\end{array}$ \\
\hline Tevkifhane & 58 & 2 & 12 Erkek \\
\hline Hapishane & 8 & 1 & 1 Erkek \\
\hline
\end{tabular}

Tablodan anlaşıldığı üzere hapishanenin tevkifhane kısmının mevcudu 58 erkek 2 kadın olmak üzere toplam 60 kişidir. Mahkûmların sayısı ise 8 erkek ve 1 kadın toplamda 9 kişi olarak kaydedilmiştir. 18 yaşından küçük olan kimselerin de işlendiği tabloda tevkifhanede 12 , hapishanede ise 1 erkek bulunmaktadır. Ancak tablodan bu kişilere dair verilen sayıların mevcut erkek sayıları dahilinde mi yoksa haricinde mi olduğunu anlamak pek mümkün olamamaktadır. Yine de 1917 yılına gelindiğinde 1915 yılına göre bir miktar azalma olduğu anlaşllabilmektedir.

Bir sonraki seneye ait veriler Şubat, Mart ve Mayıs-Ağustos aylarını kapsayan üç ayrı tablo olarak hazırlanmıştır. Bu istatistik cetvellerinde yine suç türlerine göre mahkûm ve tutukluların sayıları gösterilmektedir. Söz konusu tablolarda yer alan veriler şu şekildedir:

2020

Tablo 8: 1918 Yılı Şubat Ayına Ait Çarşamba Hapishanesi Yoklama Cetveli ${ }^{35}$

\begin{tabular}{|c|c|c|c|c|c|c|c|c|c|c|c|c|}
\hline \multicolumn{3}{|c|}{ Kabahat } & \multicolumn{3}{|c|}{ Cünha } & \multicolumn{3}{|c|}{ Cinayet } & \multirow[t]{2}{*}{ Açıklama } & \multicolumn{3}{|c|}{ Tutuklu } \\
\hline $\begin{array}{l}\text { 总 } \\
\text { 亲 }\end{array}$ & 胥 & 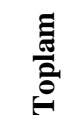 & 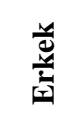 & 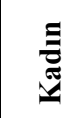 & 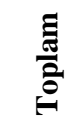 & $\begin{array}{l}\text { 竞 } \\
\text { 亲 }\end{array}$ & 吾 & 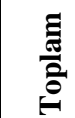 & & 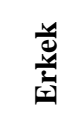 & 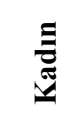 & 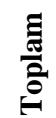 \\
\hline- & - & - & 56 & 1 & 57 & - & - & - & $\begin{array}{l}\text { Cünha ile } \\
\text { tutuklu }\end{array}$ & 56 & 1 & 57 \\
\hline - & - & - & 5 & - & 5 & - & - & - & $\begin{array}{c}\text { Silah } \\
\text { muhakemes } \\
\text { inde cünha } \\
\text { ile tutuklu }\end{array}$ & 5 & - & 5 \\
\hline
\end{tabular}

\footnotetext{
${ }^{34}$ BOA (Devlet Arşivleri Başkanlığı Osmanlı Arşivi) Dahiliye Nezareti Mebani-i Emiriye-Hapishaneler Müdüriyeti Evrakl (DH. MB. HPS), 27/17, 24 Ocak 1917 (11 Kanun-1 Sani 1332).

${ }^{35}$ BOA (Devlet Arşivleri Başkanlığı Osmanlı Arşivi) Dahiliye Nezareti Mebani-i Emiriye-Hapishaneler Müdüriyeti Müteferrik Evrakl (DH. MB. HPS. M), 34/34, 26 Ocak 1918 (26 Kanun-1 Sani 1334).
} 
Osmanlı Devleti'nde Hapishanelerin Islah Çalışmalarına Dair Bir İnceleme: Çarşamba Hapishanesi

\begin{tabular}{|l|l|l|l|l|l|l|l|l|l|l|l|l|}
\hline- & - & - & 3 & & 3 & - & - & - & $\begin{array}{c}\text { Cünha ile } \\
\text { mahkûm }\end{array}$ & 3 & - & 3 \\
\hline
\end{tabular}

Tablo 9: 1918 Yılı Mart Ayına Ait Çarşamba Hapishanesi Yoklama Cetveli ${ }^{36}$

\begin{tabular}{|c|c|c|c|c|c|c|c|c|c|c|c|}
\hline \multicolumn{3}{|c|}{ Kabahat } & \multicolumn{3}{|c|}{ Cünha } & \multicolumn{3}{|c|}{ Cinayet } & \multicolumn{3}{|c|}{ Tutuklu } \\
\hline 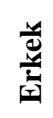 & 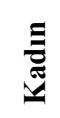 & 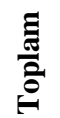 & 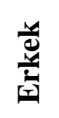 & 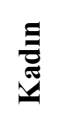 & 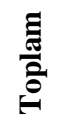 & $\begin{array}{l}\text { 莺 } \\
\text { 亲 }\end{array}$ & 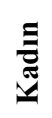 & 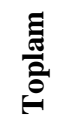 & 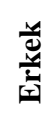 & 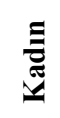 & 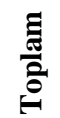 \\
\hline - & - & - & 3 & 0 & 3 & - & - & - & 61 & 1 & 62 \\
\hline
\end{tabular}

Tablo 10: 1918 Yılı Mayıs-Ağustos Aylarına Ait Çarşamba Hapishanesi Yoklama Cetveli $^{37}$

\begin{tabular}{|c|c|c|c|c|c|c|c|c|c|c|c|}
\hline \multicolumn{3}{|c|}{ Kabahat } & \multicolumn{3}{|c|}{ Cünha } & \multicolumn{3}{|c|}{ Cinayet } & \multicolumn{3}{|c|}{ Tutuklu } \\
\hline 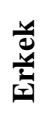 & 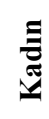 & 芯 & 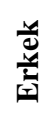 & 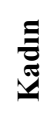 & 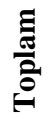 & 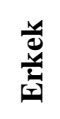 & $\underset{\Xi}{\Xi}$ & 节 & 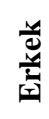 & 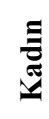 & 章 \\
\hline- & - & - & 5 & - & 5 & - & - & - & 30 & - & 30 \\
\hline
\end{tabular}

Volume 12

Yukarıda üç ayrı tabloda 1918 yılının farklı aylarına ait veriler gösterilmektedir. 1918 yılı içerisinde elimizdeki verilerden tespit edilebildiği kadarıyla hapishane mevcudunun en yüksek olduğu aylar Şubat ve Mart aylarıdır. Mayıs-Ağustos aylarına ait veriler incelendiğinde ise bir önceki aylara göre sayıca bir düşüş olduğu anlaşılmaktadır. 1918 y1lı Mart ayı özelinde Çarşamba hapishanesi 62 kişiyle Canik Sancağına bağlı, merkez kaza hariç, diğer kazalardan daha çok kişiyi barındırmaktadır. Çarşamba hapishanesini 55 kişiyle Bafra, 31 kişiyle Ünye, 27 kişiyle Terme, 12 kişiyle de Fatsa kazası takip etmektedir. Bu dönemde merkez kaza hapishanesinde ise 248 kişi bulunmaktadır. ${ }^{38} 1919$ yllında ise hapishanede 18 tutuklunun bulunduğu ve hapishanede herhangi bir olumsuz durumun yer almadiğı kaynaklarda zikredilmektedir. $^{39}$

Elbette hapishanede kalan kişilerin hayatları yalnızca sayısal değerlerden ibaret değildi. Cezalarını çekmek üzere bazen birkaç ay, bazen de uzun yıllar mahkûmiyet alan kimseler

\footnotetext{
${ }^{36}$ BOA (Devlet Arşivleri Başkanlığ ${ }_{1}$ Osmanlı Arşivi) Dahiliye Nezareti Mebani-i Emiriye-Hapishaneler Müdüriyeti Evrakı (DH. MB. HPS), 160/57, 21 Mart 1918 (1 Mart 1334)

${ }^{37}$ BOA (Devlet Arşivleri Başkanlığı Osmanlı Arşivi) Dahiliye Nezareti Mebani-i Emiriye-Hapishaneler Müdüriyeti Evrakı (DH. MB. HPS), 161/52, 9 Eylül 1918 (9 Eylül 1334).

38 Mucize Ünlü, "Hapishane Reformu Sürecinde Canik Hapishanesini Islah Çalışmaları (1876-1918)," Samsun Araştırmaları, Ed. Cevdet Yılmaz, Samsun Büyükşsehir Belediyesi Kültür Yayınları, Samsun 2013, s. 255.

${ }^{39}$ BOA (Devlet Arşivleri Başkanlığı Osmanlı Arşivi) Dahiliye Nezareti Mebani-i Emiriye-Hapishaneler Müdüriyeti Müteferrik Evrakı (DH. MB. HPS. M), 40/60, 9 Kasım 1919 (9 Teşrin-i Sani1335).
} 
hapishanelerin sağladığı şartlar dahilinde günlerini geçirmekteydi. Bu noktada mahkûmların hapishanede bulundukları sürede hangi koşullarda yaşayacakları ve onlara hangi hizmetlerin sağlanacağ 1 gibi konular önem arz etmektedir. Öyle ki, 1890 yılında Petersburg'da düzenlenen Hapishaneler Kongresi'nde konuşulan birçok gündem maddesi mahkûmların hapis hayatı ile doğrudan alakalıdır.

Yukarıda zikredildiği üzere kongrede pek çok konu ele alınmıştı ve bunlardan birçoğu mahkûmların hapishanelerdeki yaşam koşullarını doğrudan etkileyecek mahiyetteydi. Bu hususlardan birisi mahkûmların cezalarını çekerken aynı zamanda çalıştırılması konusuydu. Kongrenin ikinci oturumunda gündeme gelen bu konu hem mahkûmların hem de idarenin ihtiyaçlarının karşılanması noktasında önemli görülmüştür. Mahkûmların çalıştırılmasıyla âtıl vaziyette olan iş gücünden istifade edilmesi ve ekonomiye katkı sağlanması üzerinde durulmuştur. ${ }^{40}$ Osmanlı Devleti aslında bu kongreden çok daha önce hazırlamış olduğu "Memâlik-i Mahrûsa-yl Şâhâne'de Bulunan Tevkifhane ve Hapishanelerin İdare-i Dahiliyelerine Dair Nizamname" adlı nizamnamede de mahkûmların çalıştırılması konusunu ele almıştır. ${ }^{41}$

$\mathrm{Bu}$ hususta hapishanelere dair hazırlanan istatistik cetvellerinin hepsinde olmasa da bazılarında mahkûmiyeti esnasında çalıştırılan kişilere ait verilere yer verildiği görülmektedir. Çarşamba hapishanesinin 1917 yılına ait yoklama cetvelinde siyasi suçlular haricinde cezasını tamamlamaya altı ay kalmış çiftçi ve yol tamiri işinde çalışabilecek 3 kişinin bulunduğu kaydedilmiştir. Bunun haricinde kamu yararına çalışanlar, hapishane işlerinde görev alanlar, hususi siparişlerin imalatında görevliler ve herhangi bir işte görev almayanlara ait ayrı bir parantez açılmış olsa da söz konusu sene içerisinde bu şekilde görevlendirilen kimsenin bulunmadı $\breve{s} 1$ anlaşılmaktadır. ${ }^{42}$

Hapishane Reformu sürecinde mahkûmların temel ihtiyaçlarının karşılanması meselesi de

Volume 12

Issue 3

June

2020 önemli bir konu olagelmiştir. Bu hizmetlerin en başında mahkûmların beslenme konusundaki ihtiyaçlarının tedarik edilmesi gelmektedir. Bunun hakkında zaman zaman merkezden vilayetlere hapishanede bulunan kişilerin ekmeksiz ve dahi ilaçsız bırakılmamaları hususunda yazılar gönderilmiştir. ${ }^{43}$ Devlet tarafından hapishanedeki mahkûmlara nan-ı aziz talimatnamesi gereğince gıda hizmeti de sunulmuştur. Çarşamba hapishanesinde de mahkûmların bu tarz ihtiyaçları talimatname uyarınca giderilmekteydi. Çarşamba hapishanesinde mahkûmlara gıda temini hapishane mutfağından karşılanabildiği gibi aynı zamanda bir yardım cemiyeti veyahut bir kuruluş tarafindan da karşılanabiliyordu. Bunun dişında mahkûmlar isterlerse kendi paralarıyla gardiyanlar aracılığı ile dışarıdan yiyecek satın alabilmekteydiler. Ayrıca mahkûmlar içerisinde kendi yemeğini kendisi pişirmek isteyenler olursa hapishanenin açık alanında yemek pişirilmesine de müsaade edilmekteydi. ${ }^{44}$

\footnotetext{
${ }^{40}$ Demirel, a.g.m., s.11,13.

${ }^{41}$ Yildiz, a.g.e., s.485.

${ }^{42}$ BOA (Devlet Arşivleri Başkanlığı Osmanlı Arşivi) Dahiliye Nezareti Mebani-i Emiriye-Hapishaneler Müdüriyeti Evrakı (DH. MB. HPS), 27/17, 24 Ocak 1917 (11 Kanun-1 Sani 1332).; Tuğba Kara, "Çarşamba Hapishanesi (18941920)", Çarşamba Araştırmaları, Ed. Cevdet Yılmaz, Çarşamba Belediyesi Kültür Yayınları, Samsun 2014, s.71.; Hapishaneler ile ilgili bahsi geçen bu ayrıntılı çalışmalar 1916 senesinde hapishaneler genel müfettişliğine atanan Alman Dr. Paul Pollitz'in öncülügünde başlatıldı. Dr. Pollitz bu çalışma ile hapishanelerin mevcut vaziyetini tespit etmeyi amaçlamaktaydı. İzahat varakası olarak kayıtlara geçen bu formlarda, hapishanenin bulunduğu mahallerin isimlerinden idari personele hatta hapishanedeki mahkûm ve mevkuf adedine varıncaya kadar çeşitli sorular yer almaktaydı. Halim Demiryürek, "Hüdavendigar Vilayetinde Hapishaneler ve Mahpuslar (1914-1917), Uluslararası Sosyal Araştırmalar Dergisi, C.9, S.42, Şubat 2016, s.553.

43 BOA (Devlet Arşivleri Başkanlığı Osmanlı Arșivi) Dahiliye Nezareti Tesri-i Muamelat ve Islahat Komisyonu (DH. TMIK. S), 19/1, 20 Mayis 1898 (28 Zilhicce 1315).

${ }^{44}$ BOA (Devlet Arşivleri Başkanlığı Osmanlı Arşivi) Dahiliye Nezareti Mebani-i Emiriye-Hapishaneler Müdüriyeti Evrakı (DH. MB. HPS), 27/17, 24 Ocak 1917 (11.Kanun-1 Sani 1332).; Hapishanede kalan mahkûmların ihtiyaç duydukları gıda temini konusunda zaman zaman şikayetler ve bu konuda alınan önlemler olduğu anlaşılmaktadır. Bu
} 
Hapishanelerde sıklıkla karşılaşılan durumlardan birisi de mahkûmlar tarafından gerçekleştirilen firar teşebbüsleriydi. Bu durum bazen hapishanelerin kalabalık olmasından bazen görevlilerin dikkatsizliğinden bazen de görevli memurların müsamaha göstermesinden kaynaklanmaktayd $1 .{ }^{45}$ Çarşamba hapishanesinde de bu tarz girişimler yok değildir. Tespit edebildiğimiz ilk firar hadisesi 1899 yılında gerçekleşmiştir. Bu eylem neticesinde sekiz kişi hapishaneden firar etmiştir. Olayın hemen ardından şahısları yakalamak için gerekli işlemlerin başlatılması istenilmiştir. Ayrıca durumun araştırılması ve olayda suçu olanların tespit edilmesi hususunda gerekli adımlar atılmıştır. ${ }^{46}$ Bir diğer firar teşebbüsü ise 14 yıl arayla yani 1913 yılında gerçekleşmiştir. Ancak olayla ilgili yazışmalardan takip edilebildiği kadarıyla bu girişim başarıya ulaşamadan tespit edilip engellenmiştir. Yalnız hapishanenin menfezi ciddi oranda zarar görmüştür. ${ }^{47}$

Hapishanelerde gerçekleşen bu gibi istenmeyen durumlar yetkililer tarafından bir takım önemlerin alınmasını zorunlu kılmıştır. Bu anlamda mahkûmlara tek tip elbise giydirilmesi gündeme gelmiş, buna ilave olarak mahkûmların silah tedarik edebilmelerinin önüne geçilmeye çalışılmıştır. Hapishanelerin düzeni ve ıslahı kapsamında mahkûmlara tek tip elbise giydirmesiyle firar etmeleri durumunda daha kolay yakalanmaları amaçlanmıştır. Aynı zamanda alınacak bu önemler hapishanelerin ahvali için gereken tedbirlerden en önemlisi ve en acil olanları arasında zikredilmiştir. ${ }^{48}$

Çarşamba hapishanesinde sayıları erkeklere nazaran çok daha az olsa da kadın mahkûmlar da bulunmaktaydı. Her ne kadar hapishanelerin 1slahı konusunda Osmanlı Devleti tarafindan yaptırılan çalışmalarda kadın mahkûmlar için özel hapishanelerin yapılması konusunda çalışmalar olsa da bu, taşradaki her hapishane için mümkün olamamıştır. ${ }^{49}$ Çarşamba kazasında

hususta mahkûmların günlük ihtiyaç duydukları kalori miktarının hesaplanması ve gıda eksikliği nedeniyle mahkûmların herhangi bir şekilde hastalık gibi durumlarla karşılaşmaması için gereken önlemlerin alınması konusunda yazışmalar da yapılmıştır. Bkn: BOA (Devlet Arşivleri Başkanlığı Osmanlı Arşivi) Dahiliye Nezareti Mebani-i Emiriye-Hapishaneler Müdüriyeti Evrakl (DH. MB. HPS), 80/22, 6 Mart 1917 (12 Cumaziyelevvel 1335).; Mahkûmların hapishanede yapmış oldukları işlerden kazandıkları parayı yine hapishanede bulundukları müddet boyunca harcayabilmeleri konusu Petersburg Hapishaneler Kongresi'nde de konuşulmuş ve bu hususta görüş birliği oluşmuştur. $\mathrm{Bu}$ nedenler mahkûmlar iaşelerini ve kazandıkları paralarını dışarıdan yemek tedariki için de kullanabilmekteydiler. Bkn: Demirel, a.g.m, s.13.

${ }^{45}$ Hapishane olarak kullanılan bazı binaların gayet köhne ve yıkılmak üzere olması da firar teşebbüslerini arttırıcı nedenler arasında gösterilebilir. Kurtuluş Demirkol, "II. Meşrutiyet Döneminde İzmit Hapishanesi”, Uluslararası Gazi Akça Koca ve Kocaeli Tarihi Sempozyumu, Ed. Haluk Selvi, M.Bilal Çelik, İzmit 2015, s.992.

${ }^{46}$ BOA (Devlet Arşivleri Başkanlığ 1 Osmanlı Arşivi) Dahiliye Nezareti Mektubi Kalemi (DH. MKT), 2216/82, 28 Haziran 1899, (16 Haziran 1315).

${ }^{47}$ BOA (Devlet Arşivleri Başkanlığı Osmanlı Arşivi) Dahiliye Nezareti Mebani-i Emiriye-Hapishaneler Müdüriyeti Evrakı (DH. MB. HPS), 5/44, 17 Kasım 1913 (4 Teşrin-i Sani 1329); Osmanlı Hapishanelerinde firar teşebbüsleri için bkn: Ebubekir Sofuoğlu, "Osmanlı Hapishanelerinde Islah ve Firar Teşebbüsleri”, Hapishane Kitabı, Ed. Emine Gürsoy Naskali, Hilal Oytun Altun, Kitabevi Yayınları, İstanbul 2018, s.161-172.

${ }^{48}$ BOA (Devlet Arşivleri Başkanlığı Osmanlı Arşivi) Dahiliye Nezareti Tesri-i Muamelat ve Islahat Komisyonu (DH. TMIK. S), 38/65, 20 May1s 1902 (7 May1s 1318).

${ }^{49}$ Tanzimat'tan sonra şehir ve büyük kaza merkezlerinde bulunan hapishanelerin birer odasının kadın mahpuslar için düzenlenmesi planlanmıştır. Bununla birlikte imam ve muhtar evleri de kadın hükümlüler için hapishane olarak kullanılmaya devam etmiştir. 1858 yılında ise hapishaneler konusunda uzman sayılan İngiliz subayı Binbaş1 Gordon'un da katılımıyla Meclis-i Tanzimat Dairesinde özel bir komisyon toplanmıştır. Burada kadın hapishaneleri konusu da ele alınmış ve kadın mahkûmlar için özel hapishanelerin yapılması gündeme gelmiştir. 1882 tarihine gelindiğinde ise daha az masraflı olacağı için ekseriyetle taşrada olmak üzere, mevcut hapishanelerin uygun yerlerine kadınlar için bölümler inşa edilmesi planlanmıştır. Bu yolla kadın mahkûmlar için kiralanan evlere sürekli ödenen kira bedellerinden de tasarruf edilmiş olacaktı. Ali Karaca, "XIX. Yüzyılda Osmanlı Devleti'nde Fahişe Hatunlara Uygulanan Cezalar: Hapis ve Sürgün”, Hapishane Kitabı, Ed. Emine Gürsoy Naskali, Hilal Oytun Altun, Kitabevi Yayınları, İstanbul 2018, s. 154-156.; Osmanlı'da kadın hapishaneleri hakkında detaylı bilgi için bkn: Saadet Tekin, "Osmanlı'da Kadın ve Kadın Hapishaneleri”, Ankara Üniversitesi Tarih Araştırmaları Dergisi, 29/47, 2010, ss.83-102.; Hapishaneler öncesi kadın mahkûmlar hakkında detaylı bilgi için bkn: Mucize Ünlü, Volkan 
da kadınlar için müstakil bir hapishane binasına rastlanılmamaktadır. Bu nedenle zaman zaman kazada kadınlara mahsus bir hapishane binası yapılması için yazışmalara rastlanmaktadır. ${ }^{50}$ Kazanın kadınlara hususi bir hapishaneden mahrum olması nedeniyle kadın tutuklu ve suçlular jandarma dairesinin alt katında bulunan eşya mahzeninde tutulmaktaydı. Ancak buradaki mevcut şartların sağlık açısından pek elverişli olmaması mahkûmların sık sık hasta olmalarına neden olmakta ve bu durum belediye tabipleri tarafindan da dile getirilmekteydi. Bunun yanı sıra kadın mahkûmların ikamet ettirildiği odanın jandarma binasında bulunması da sakıncalı görülmüştür. ${ }^{51} \mathrm{Bu}$ nedenle kadın mahkûmlar için hapishane olarak inşa edilecek bağımsız bir binaya ihtiyaç duyulduğu yapılan yazışmalarda özellikle belirtilmiştir. Fakat bu dönemde devletin ekonomik olarak zor durumda bulunması bu konuda maddi kaynak ayrılmasını mümkün kılmamıştır. Fakat geçici bir süre ile zor koşullar altında olan kadın mahkûmlar için bir hane kiralanması ve orada ikamet ettirilmeleri planlanmıştır. Bunun için ise senelik altı yüz kuruş kiralama bedeli kaymakamlık vasıtasıyla talep edilmiştir. Fakat hapishaneler dairesi müdüriyeti, içinde bulunulan sene bütçesinden bu miktarın karş1lanmasının mümkün olmadığını bildirmiştir. Bu koşullar altında kadın mahkûmların halihazırda tutuldukları yerin mümkün mertebe tamir edilerek kullanılması tavsiye edilmiştir. ${ }^{52}$

\section{3- Hapishane Personeli}

Hapishanelerde düzenin ve asayişin tesis edilebilmesi ve sorunsuz bir şekilde sürdürülebilmesi hapishane personeline önemli sorumluluklar yüklemekteydi. Hapishane idaresinin sağlanması, mahkûmların ihtiyaçlarının giderilmesi ve diğer yapılması lazım gelen işlerin muntazam bir şekilde yürütülmesi ancak iyi bir ekip ile mümkündü. $\mathrm{Bu}$ nedenle hapishanelerde görev yapacak memurların konunun önemini haiz ve yeterli donanıma sahip olmaları büyük önem arz etmekteydi. Konunun ehemmiyetine binaen 1880 nizamnamesinde

Volume 12

Issue 3

June

2020 hapishane personelinin görev, yetki ve sorumlulukları açıkça belirtilmişti.

Hapishane personelinin seçimi meselesi diğer ülkeler için de önem arz etmekteydi. $\mathrm{Bu}$ nedenle Petersburg Hapishaneler Kongresi'nin ilk oturumunda görüşülen konulardan biri de bu olmuştur. Hapishanede görev yapacak personelin usul-i habsiye konusunda bilgili olmas1 gerektiği üzerinde durulmuştur. Buna dair ilimlerin okullarda okutulmasının faydalı olacağ 1 hatta hukuk mekteplerinde bu konuda bir dersin açılması konusu görüşülmüştür. Aynı zamanda bu hususta kitaplar yazılması ve bir kütüphane oluşturulması da konuşulan konuların arasındadır. Diğer bir yandan ise memurların belirli sınavlardan ve stajlardan geçmesi gerekliliği gündeme gelmiştir. Görevlilerin görevlerini suiistimal etmelerini önlemek adına ise maaşlarının vazifelerinin önemine uygun bir şekilde düzenlenmesinin faydalı olacağ 1 hususunda fikir birliğine varılmıştır. ${ }^{53}$

Çeribaş, "Kalebend Defterlerine Göre Osmanlı'da Kadın Mahkûmlar (1800-1815)", Osmanlı Mirası Araştırmaları Dergisi, 6/16, 2019, ss.535-553.

${ }^{50}$ BOA (Devlet Arşivleri Başkanlığı Osmanlı Arşivi) Dahiliye Nezareti Tesri-i Muamelat ve Islahat Komisyonu (DH. TMIK. S), 56/12, 12 Kasım 1904 (4 Ramazan 1322).; BOA (Devlet Arşivleri Başkanlığı Osmanlı Arşivi) Dahiliye Nezareti Mektubi Kalemi (DH. MKT), 2177/35, 13 Mart 1899, (1 Mart 1315).

${ }^{51}$ Kara, a.g.m., s.66.

${ }^{52}$ BOA (Devlet Arşivleri Başkanlığı Osmanlı Arşivi) Dahiliye Nezareti Mebani-i Emiriye-Hapishaneler Müdüriyeti Evrakı (DH. MB. HPS), 2/7, 25 Aralık 1911 (4 Muharrem 1330).

${ }^{53}$ Demirel, a.g.m., s.12.; Memur ve gardiyan gibi personel seçimine dair birtakım kriterler ve özellikler, 1912 tarihli Nizamname'de belirtilmiştir. Nizamnamede seçilecek hapishane müdürlerinin ceza kanununa vâkıf, güzel ahlak ve otorite sahibi olması şartı vardır. Fakat bu niteliklere sahip kişilerin sınavı başarıyla tamamlamaları ve sonrasında tayin edilmeleri uygun görülmüştür. Bu kişiler içinde de askeriyeden istifa etmiş zabitlere öncelik tanınması ve eğer şartları taşıyorsa öncelikli olarak tayinlerinin tamamlanması belirtilmektedir. Gardiyan olarak görevlendirilecekler 
Çarşamba hapishanesi idari personelleri hakkında tespit edebildiğimiz ilk kayıtlar 1894 tarihine aittir. Söz konusu vesikada Çarşamba hapishanesinde herhangi bir görevli memur ve gardiyanın olmadığ 1 belirtilmektedir. Hapishanenin idaresi ise bu süreçte zabıtanlar tarafından yürütülmektedir. $\mathrm{Bu}$ durumun hapishanedeki işlerin aksamasına ve usulsüzlüklerin yaşanmasına da neden olduğu bilinmektedir. Hapishanede herhangi bir görevlinin bulunmadığ bu dönemde bir köy muhtarının usulsüz yere hapishaneye alınması ve yapılan teftiş neticesinde durumun ortaya çıkarılmasıyla hapishanenin idari anlamda ıslahı zaruri görülmüştür. ${ }^{54}$

Söz konusu vesikadan anlaşıldığı kadarıyla hapishanelerin idaresi ve buralarda görev alacak memurlar anlamında birtakım sıkıntılar yaşanmaktadır. Bir benzer durum kadın hapishanesi olarak kullanılan mahaller için de gözlemlenmektedir. Çarşamba, Ünye ve Terme kazalarında kadın mahkûmlar için kiralanan yerlerde kadın gardiyanların bulunmadığı ve ihtiyaç duyulduğu anlaşılmaktadır. Bu durum özelinde kaçar tane kadın gardiyanın istihdam edileceği ve bunlara ödenecek maaş hakkında üst makamlara görüş sorulmuştur. ${ }^{55}$

Hapishanelerde görev yapan personel sayısı hapishanenin büyüklüğü ve mahkûm yoğunluğuna göre değişiklik göstermekteydi. ${ }^{56}$ Örneğin; Canik Sancağı merkez hapishanesinde müdür, kâtip ve 8 gardiyan görev almaktaydı. Ancak Çarşamba, Bafra, Terme, Ünye ve Fatsa gibi kaza hapishanelerinde yalnızca 2 görevli mevcuttu. Çarşamba hapishanesinde müdürlük pozisyonunda kimse bulunmamakta, bir baş gardiyan bir de gardiyan görev yapmaktaydı. Baş gardiyanlık görevi Mihail Efendi, gardiyanlık görevi ise Cavid Efendi tarafindan yürütülmekteydi. ${ }^{57}$

Hapishane görevlilerinin maaşları sabit olup, baş gardiyan 200 kuruş, gardiyanlar ise 160 kuruş ücret almaktaydılar. ${ }^{58} 1915$ senesine ait bir vesikada da yine Çarşamba hapishanesinde bir baş gardiyan ve bir gardiyan olarak kişi görevlinin bulunduğu, aldıkları ücretlerde de herhangi bir değişikliğin bulunmadığı anlaşılmaktadır. ${ }^{59}$

için ise 1910 tarihli bir kayıtta okuma yazma bilmelerinin gerekli olduğu yazılmaktadır. Bazı yerlerde bu hususa dikkat edilmeden gardiyanlar görevlendirildiği konusunda şikayetler de yer almaktadır. Bkn: Şen, a.g.e., s.152,153.

$54 \mathrm{Bu}$ tarihte Çarşamba hapishanesinin yanında Bafra, Ünye ve Terme hapishanelerinde de görevli memur bulunmamaktadır. BOA (Devlet Arşivleri Başkanlığı Osmanlı Arşivi) Dahiliye Nezareti Mektubi Kalemi (DH. MKT), 303/50, 4 Kasım 1894 (23 Teşrin-i Evvel 1310).; Hapishane ve tevkifhanelerde ihtiyaca göre bir müdür, başkatip, katipler, bir başgardiyan, gardiyanlar, tabip, çamaşırcı, bir aşçı, bir imam ve kadın hapishaneleri için de kadın gardiyanlar görevlendirilebilmekteydi. Halim Demiryürek, Osmanlı Hapishaneleri (1913-1914), Babıali Kültür Yayıncılığı, İstanbul 2019, s.23.

${ }^{55}$ BOA (Devlet Arşivleri Başkanlığı Osmanlı Arşivi) Dahiliye Nezareti Mektubi Kalemi (DH. MKT), 2177/35, 13 Mart 1899 (1 Mart 1315).

${ }^{56} 1912$ yılında yapılan araştırma ile Avrupa hapishaneleri incelenmiş ve kaç mahpusa karşılık kaç gardiyanın görev yaptığı bilgisi temin edilmiştir. Buna göre Osmanlı hapishanelerinde Avrupa'ya kıyasla daha fazla görevli çalıştığı tespit edilmiştir. Bkn: Şen, a.g.e., s.154.

${ }^{57}$ BOA (Devlet Arşivleri Başkanlığı Osmanlı Arşivi) Dahiliye Nezareti Mebani-i Emiriye-Hapishaneler Müdüriyeti Müteferrik Evrakı (DH. MB. HPS. M), 5/18, 5 Haziran 1912 (23 Mayıs 1328).

${ }^{58}$ BOA (Devlet Arşivleri Başkanlığ ${ }_{1}$ Osmanlı Arşivi) Dahiliye Nezareti Mebani-i Emiriye-Hapishaneler Müdüriyeti Müteferrik Evrakı (DH. MB. HPS. M), 5/18, 5 Haziran 1912 (23 Mayıs 1328). Merkez hapishanede görev yapan müdür 300 kuruş, kâtip ise 200 kuruş ücret almaktaydı. Ancak merkez hapishanede görev yapan hapishane müdürünün maaşı, bir gardiyanın olmamasından dolayı gardiyan maaşı kadar zam yapılarak 14 Mayıs 1912 tarihinden itibaren 460 kuruşa çıkarılmıştır.

${ }^{59}$ BOA (Devlet Arşivleri Başkanlığı Osmanlı Arşivi) Dahiliye Nezareti Mebani-i Emiriye-Hapishaneler Müdüriyeti Evrakı (DH. MB. HPS), 155/100, 8 Kasim 1915 (30 Zilhicce 1333). 
Yukarıda değinildiği üzere hapishanelerin iyi bir şekilde idare edilebilmesi buralarda çalışan personellerin işlerini iyi yapmaları ile doğrudan alakalıydı. Görevini iyi yapan, sorumluluklarını yerine getirenler olduğu kadar suiistimal edenler de mevcuttu. Devlet ise her iki durum için de gereğini yapmaktan geri durmamış, görevini kötüye kullananları cezalandırılırken, diğer taraftan mükafatlandırılan kişiler de olmuştur. Bu hususta 1912 senesi mart ayından 1913 senesinin nisan ayına kadar Çarşamba hapishanesinde baş gardiyanlık görevini yürüten Mahmud Ağa, görevini suiistimal ettiğinden açığa alınmıştır. Mahmud Ağa'nın görevden alınmasıyla aynı pozisyona getirilen Mehmed Efendi ise atanmasının üzerinden çok bir zaman geçmeden başka bir göreve terfi ettirilmiştir. Aşağıda yer alan tabloda 1911 senesinden 1913 senesi sonuna kadar Çarşamba hapishanesinde görev yapan kişilerin listesi ve detayları mevcuttur.

Tablo 11: 1911-1913 Yılları Çarşamba Kazası Hapishanesi Görevlileri ${ }^{60}$

\begin{tabular}{|c|c|c|c|c|}
\hline & Göreve Başlama & Görevden Ayrılma & Adı & Açıklama \\
\hline$\frac{\frac{\text { HISTORY }}{\text { STUDIES }}}{\mathbf{1 0 7 9}}$ & 6 Mart 1912 & 30 Nisan 1913 & $\begin{array}{c}\text { Başgardiyan } \\
\text { Mahmud Ağa }\end{array}$ & $\begin{array}{l}\text { Vazifesini suiistimal } \\
\text { ettiğinden açığa } \\
\text { alınmıştır. }\end{array}$ \\
\hline \multirow[t]{3}{*}{$\begin{array}{c}\text { Volume } 12 \\
\text { Issue } 3 \\
\text { June } \\
2020\end{array}$} & 14 Haziran 1913 & 12 Kasım 1913 & $\begin{array}{c}\text { Başgardiyan } \\
\text { Mehmed Efendi }\end{array}$ & $\begin{array}{l}\text { Ünye Süvari } \\
\text { mübaşirliğine terfi } \\
\text { etmiştir. }\end{array}$ \\
\hline & 24 Ekim 1913 & - & $\begin{array}{c}\text { Başgardiyan Arif } \\
\text { Efendizade Hasan } \\
\text { Efendi }\end{array}$ & $\begin{array}{l}\text { Açıktan tayin } \\
\text { olunmuştur. }\end{array}$ \\
\hline & 23 Ağustos 1911 & - & $\begin{array}{l}\text { Gardiyan Mehmed } \\
\text { Cavid Efendi }\end{array}$ & $\begin{array}{l}\text { Eski memuriyetine } \\
\text { yeniden atanmıştır. }\end{array}$ \\
\hline
\end{tabular}

Tablodan da anlaşıldığı üzere, hapishanelerde istihdam edilen personel görevinin gerektirdiği şekilde davranmakla mesuldü. Aksi taktirde açığa alınarak görevine son verilmekteydi. Aynı şekilde çalışmasından memnun kalınan kişiler için de terfi sistemi işletilmekteydi. Hapishanelerdeki mevcut durumların iyileştirilmesi ve ıslahı anlamında görevlilere de sorumluluklar yüklenmekte ve kendisinden memnun kalınmayan kişiler için soruşturma da açılabilmekteydi. Özellikle mahkûmların firar etmeleri veyahut firara teşebbüse

${ }^{60}$ BOA (Devlet Arşivleri Başkanlığ ${ }_{1}$ Osmanlı Arşivi) Dahiliye Nezareti Mebani-i Emiriye-Hapishaneler Müdüriyeti Müteferrik Evrakı (DH. MB. HPS. M), 12/56, 8 Nisan 1914 (26 Mart 1330). 
kalkışmaları halinde görevlilerin olayda herhangi bir rolü veya müsamahası olup olmadığı araştırılmaktaydı. ${ }^{61}$

\section{Sonuç}

Osmanlı Devleti'nde Hapishane Reformu süreci Tanzimat devri ile başlamış ve cihan harbi yıllarında dahi devam etmiştir. XIX. yüzyıla kadar hapishane olarak adlandırılabilecek müstakil yapıların bulunmaması nedeniyle tutuklular ve mahpuslar aynı yerlerde tutulmaktaydı. Ancak bu yerlerin fiziki olarak yetersizlikleri ve genel sağlık koşulları açısından uygun olmamaları yeni hapishane binaları inşasını gerekli kılmıştır. Aynı zamanda buralarda uygulanacak nizama dair de emirler yayınlanmıştır. Devlet, hapishaneler konusunda uluslararası toplantılara katılmış ve bu hususta yapmış olduğu çalışmaları Avrupalı devletleri nazarında da göstermek istemiştir.

Hapishaneler hakkında hazırlanan nizamnamede her kaza, liva ve vilayet dahilinde birer tevkifhane ve hapishane bulundurulması kararlaştırılmışsa da kâğı üzerinde alınan kararların eyleme dönüşmesi ise her zaman mümkün olamamıştır. Her ne kadar payitahtta özel bir hapishane binası teşekkül edilebilmişse de bu dönemde taşrada hapishane standartlarına uygun inşa edilmiş yapılara rastlamak oldukça güçtür. Yine de hapishanelerin ıslahı konusunda pek çok yerde hapishane olarak kullanılan mahallerin iyileştirilmesine gayret edilmiş, yerel yöneticiler ile üst merciler arasında bu hususta yoğun yazışmalar gerçekleştirilmiştir.

Hapishane Reformu'nun uygulanmaya çalışıldığı yerlerden yalnızca biri olan Çarşamba Hapishanesi de gerekli koşulları taşımamakla birlikte eksiklerin tamamlanabilmesi için yoğun mesai harcanan yerlerden birisidir. Yerel yöneticilerin çalışmaları öncelikle fiziki olarak yetersiz olan binanın yenilenmesi üzerine odaklanmıştır. Genel sıhhî koşulların mahkûmlar için yeterli olmaması da bu hususta ivedi çalışmalar yapılmasını kaçınılmaz kılmıştır.

Her ne kadar yerelden yapılan talepler müstakil ve hapishane şartlarına uygun bir bina inşa edilmesi yönünde olsa da bunun mümkün olmadığı uzun yıllar boyunca yapılan yazışmalardan tespit edilmiştir. Merkezi hükümet mevcut mahallin birtakım tamiratla iyileştirilmesini mali anlamda daha uygun bulduğundan bu yönde tasarrufta bulunmuştur. Bu nedenle hapishanelerin 1slahı sürecinde Çarşamba hapishanesi yeni bir yapı kazanamamış, zaman zaman merkezden alabildiği ödeneklerle hapishane olarak kullanılan yerin iç ve dış kısmında tamirat yaparak iyileştirme çalışmalarıyla yetinmek durumunda kalmıştır.

\footnotetext{
${ }^{61}$ Hapishaneden firar olaylarına farklı hapishanelerde de rastlanmaktaydı. Hapishane-i Umumi'de gerçekleşen bir firar eyleminin ardından yapılan tahkikatta tutukluların ve mahkûmların firar ettiği, olayın gerçekleşmesinin ise gardiyanların müsamahasından kaynaklandığı anlaşılmıştır. Bu gibi olayların tekrar yaşanmaması için ise gardiyanların maaşlarının yeniden değerlendirilmesi ve hapishane olarak kullanılan yerlerin ihtiyaca göre düzenlenmesi gerektiği aksi taktirde bu tarz olayların önüne geçilemeyeceği Dahiliye Nezareti'ne bildirilmiştir. Bkn: BOA (Devlet Arşivleri Başkanlığı Osmanlı Arşivi) Dahiliye Nezareti Mebani-i Emiriye-Hapishaneler Müdüriyeti Müteferrik Evrakı (DH. MB. HPS. M), 38/84, 10 Temmuz 1919 (10 Temmuz 1335).; BOA (Devlet Arşivleri Başkanlığı Osmanlı Arşivi) Dahiliye Nezareti Mebani-i Emiriye-Hapishaneler Müdüriyeti Müteferrik Evrakı (DH. MB. HPS. M), 38/93, 12 Temmuz 1919 (12 Temmuz 1335).
} 


\section{Kaynakça}

\section{Devlet Arşivleri Başkanlığı Osmanlı Arşivi}

Dahiliye Nezareti Mebani-i Emiriye-Hapishaneler Müdüriyeti Evrakı (DH. MB. HPS):27/17, 2/7, 5/44, 143/23, 124/3, 16/49, 142/37, 27/17, 160/57, 161/52, 80/22, 155/100

Dahiliye Nezareti Mebani-i Emiriye-Hapishaneler Müdüriyeti Müteferrik Evrakı (DH. MB. HPS. M):5/1, 20/96, 34/34, 40/60, 5/18, 12/56, 38/84, 38/93

Dahiliye Nezareti Mektubi Kalemi (DH. MKT):2158/59, 2216/82, 2177/35, 303/50

Dahiliye Nezareti Tesri-i Muamelat ve Islahat Komisyonu (DH. TMIK. S):56/12, 58/50, 21/16, $19 / 1,38 / 65$

Irade Dahiliye (İ.DH.): 1176/91920

Meclis-i Vükela Mazbataları (MV.):48/55

Yıldız Esas Evrakı (Y. EE):134/53

\section{Tetkik Eserler- Makaleler}

Ahmed Lûtfî (Efendi), Vak'a-Nüvis Ahmed Lütfí Efendi Tarihi, C.XII, Yay. M. Münir Aktepe, Türk Tarih Kurumu Yayınları, Ankara 1989.

ÇERIBAŞ, Volkan, "Kalebend Defterlerinde Geçen Suç ve Ceza Türleri: 33 Numaralı Kalebend Defteri Örneği”, History Studies, 10/9, Aralık 2018, ss. 85-102.

DEMIREL, Fatmagül, “1890 Petersburg Hapishaneler Kongresi”, Toplumsal Tarih, C.15, S.89 (Mayıs 2001), ss.11-14.

DEMIRKOL, Kurtuluş, "II. Meşrutiyet Döneminde İzmit Hapishanesi”, Uluslararası Gazi Akça Koca ve Kocaeli Tarihi Sempozyumu, Ed. Haluk Selvi, M.Bilal Çelik, İzmit 2015, ss.989-1003.

DEMIRYÜREK, Halim, "Hüdavendigar Vilayetinde Hapishaneler ve Mahpuslar (1914-1917), Uluslararası Sosyal Araştırmalar Dergisi, C.9, S.42, Şubat 2016, ss.552-562.

DEMIRYÜREK, Halim, Osmanlı Hapishaneleri (1913-1914), Babıli Kültür Yayıncıllı̆ğ, İstanbul 2019.

ERLER, Mehmet Yavuz, "Karadeniz'de Avrupai Bir Kent Samsun (1865-1875)", Karadeniz Tarihi Seтроzуuтu, Cilt:1, Trabzon 2007, ss. 541-581.

İŞBILLIR, Ömer, "Kalebend", Türkiye Diyanet Vakfi İslam Ansiklopedisi, C. Ek-2, İstanbul 2016, ss.5-7.

KARA, Tuğba, "Çarşamba Hapishanesi (1894-1920)", Çarşamba Araştırmalar, Ed. Cevdet Yılmaz, Çarşamba Belediyesi Kültür Yayınları, Samsun 2014, ss.61-73.

KARACA, Ali, “XIX. Yüzyılda Osmanlı Devleti’nde Fahişe Hatunlara Uygulanan Cezalar: Hapis ve Sürgün", Hapishane Kitabl, Ed. Emine Gürsoy Naskali, Hilal Oytun Altun, Kitabevi Yayınları, İstanbul 2018, s. 154-156. 
KARACA, Ali, Anadolu Islahâtı ve Ahmet Şâkir Paşa (1838-1899), Eren Yayınları, İstanbul 1993.

KÖSE, Osman, "Canik’te Asayiş (1911-1914)", Samsun Araştırmaları, Ed. Cevdet Yılmaz, Samsun Büyükşehir Belediyesi Kültür Yayınları, Samsun 2013, ss.225-242.

GAZEL, Ahmet Ali, “Tanin Muhabiri Ahmet Şerif Beyin Notlarında Osmanlı Hapishaneleri”, Hapishane Kitabl, Ed. Emine Gürsoy Naskali, Hilal Oytun Altun, Kitabevi Yayınları, İstanbul 2018, ss.143-151.

GÖNEN, Yasemin Saner, "Osmanlı İmparatorluğunda Hapishaneleri İyileştirme Girişimi, 1917 Y1lı", Hapishane Kitabl, Ed. Emine Gürsoy Naskali, Hilal Oytun Altun, Kitabevi Yayınlar1, İstanbul 2018, ss.173-183.

SCHULL, Kent F., Prisons In The Late Ottoman Empire, Microcosms Of Modernity, Edinburgh University Press, Edinburgh 2014.

SCHULL, Kent, "Tutuklu Sayımı: Jön Türklerin Sistematik Bir Şekilde Hapishane İstatistikleri Toplama Çalışmaları ve Bunların 1911-1918 Hapishane Reformu Üzerine Etkileri”, Osmanlı'da Asayiş Suç ve Ceza, 18. 20. Yüzylllar, Der. Noémi Levy, Alexandre Toumarkine, Tarih Vakf1 Yurt Yayınları, İstanbul 2008, ss. 212-238.

SERBESTOĞLU, İbrahim, Tanzimat, Teftiş ve Canik Sancă̆ı'nda Modernleşme, Gece Akademi Yayınları, Ankara 2019.

SOFUOĞLU, Ebubekir, "Osmanlı Hapishanelerinde Islah ve Firar Teşebbüsleri”, Hapishane Kitabl, Ed. Emine Gürsoy Naskali, Hilal Oytun Altun, Kitabevi Yayınları, İstanbul 2018, s.161-172.

Şemsettin Sami, Kâmus-ı Türk̂̂, Yeditepe Yayınları, İstanbul, 2015, s.539, 540.

ŞEN, Ömer, Osmanlı'da Mahkûm Olmak, Avrupalılaşma Sürecinde Hapishaneler, Kapı Yayınları, İstanbul 2007.

ŞIMŞEK, Eyyup, "XX. Yüzyıl Başlarında Trabzon Hapishanesi (1900-1914)”, Karadeniz Incelemeleri Dergisi, 2017; 23, ss.143-162.

TEKİN, Saadet, "Osmanlı'da Kadın ve Kadın Hapishaneleri”, Ankara Üniversitesi Tarih Araştırmaları Dergisi, 29/47, 2010, s.83-102.

Türk Hukuk Lügatı, 3. Baskı, Başbakanlık Basımevi, Ankara 1991, s.116.

ÜNLÜ, Mucize, "Hapishane Reformu Sürecinde Canik Hapishanesini Islah Çalışmaları (18761918)," Samsun Araştırmaları, Ed. Cevdet Yılmaz, Samsun Büyükşehir Belediyesi Kültür Yayınları, Samsun 2013, s. 243-257.

ÜNLÜ, Mucize, Volkan Çeribaş, "Kalebend Defterlerine Göre Osmanlı'da Kadın Mahkûmlar (1800-1815)", Osmanlı Mirası Araştırmaları Dergisi, 6/16, 2019, ss.535-553.

YILDIZ, Gültekin, Mapusâne Osmanlı Hapishanelerinin Kuruluş Serüveni (1839-1908), Kitabevi Yayınları, İstanbul 2010. 


\section{Hakan Tan}

\section{EKLER}

Ek 1: Çarşamba Hapishanesi Dış Duvarının Projesi

Volume 12

Issue 3

June

2020

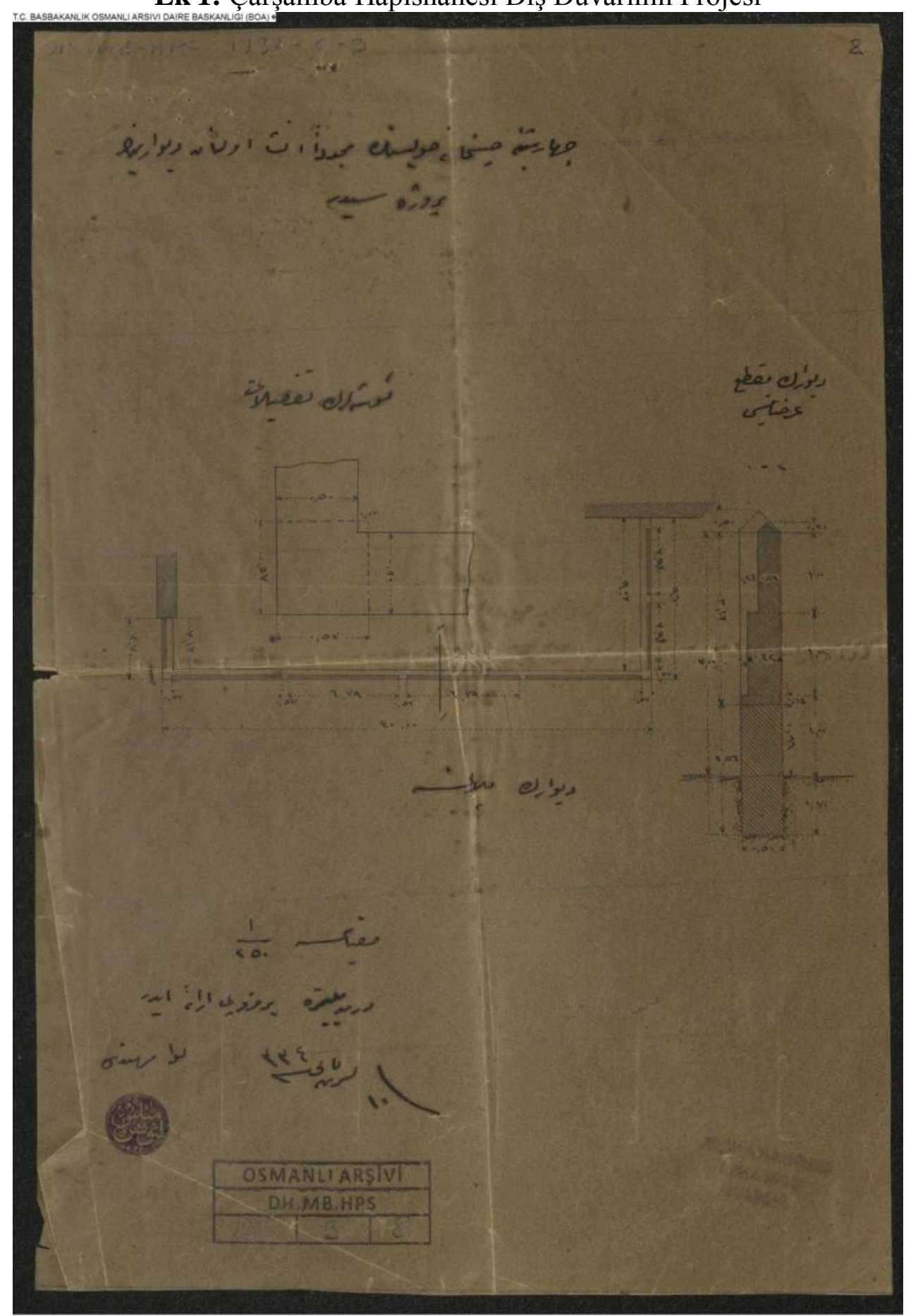

DH.MB.HPS.00124.00003.008

BOA, DH.MB.HPS 124/3

History Studies 
Ek 2: Çarşamba Hapishanesine Ait İzahat Varakası
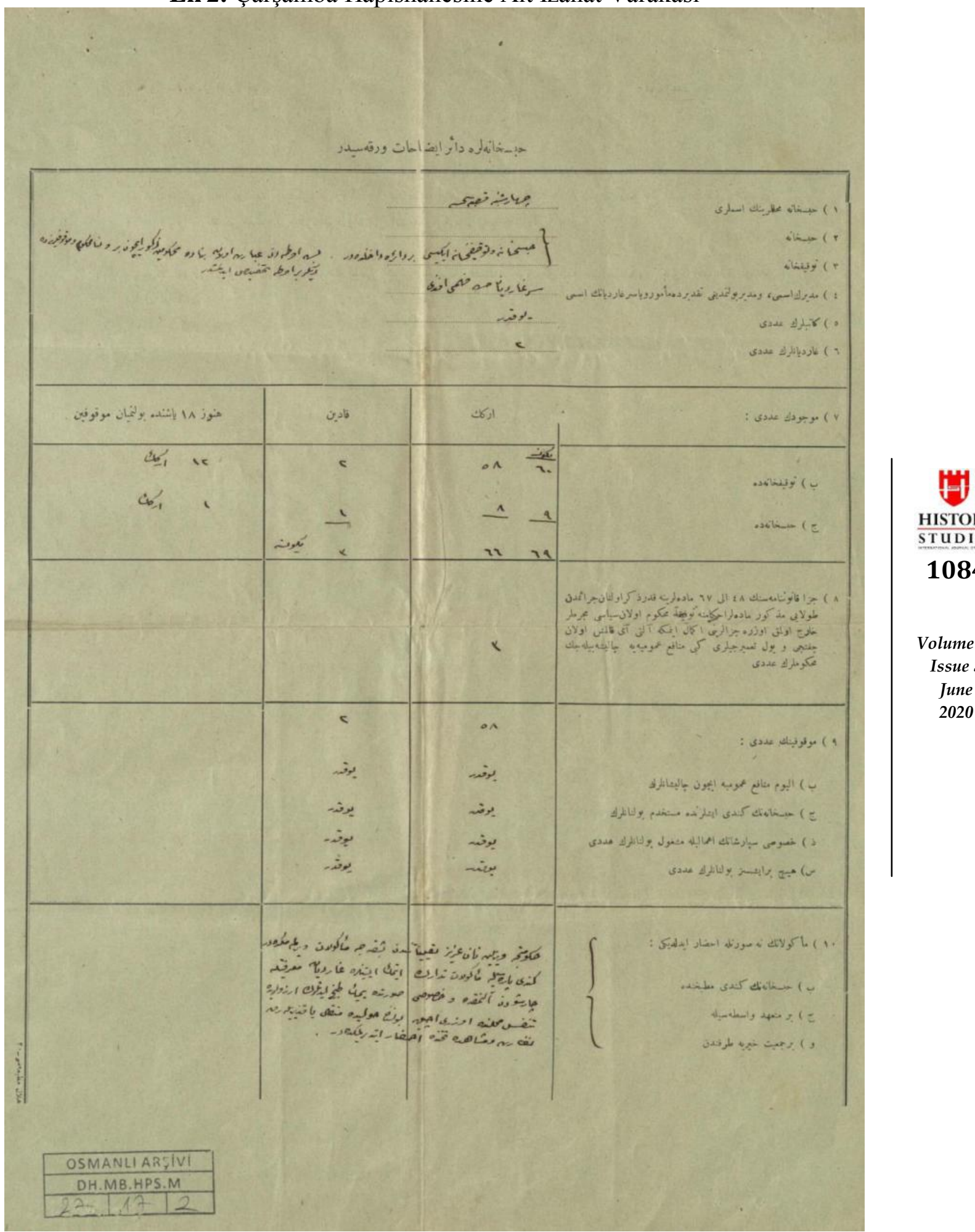

HISTORY STUDIES 1084

Volume 12

Issue 3

June

2020

BOA, DH.MB.HPS.M 27/17

History Studies 